\title{
Las mordazas a la prensa obrera. Los mecanismos de la censura política en chile, 1919-1925
}

\author{
The jaws of the working press. \\ The mechanisms of political censorship in Chile, 1919-1925
}

Karen Donoso Fritz

\begin{abstract}
Resumen
En este artículo se analizará la censura contra la prensa obrera en Chile entre 1919 y 1925, en el contexto de la cuestión social, la crisis del orden oligárquico y la reconfiguración del brazo represivo del Estado. Planteamos como hipótesis que los gobiernos privilegiaron la censura administrativa-policial por sobre la judicial por ser la legislación vigente insuficiente para contener a estos medios de comunicación caracterizados como "subversivos". Por lo anterior, en este periodo se construyó el camino para la creación de una normativa que estableció controles y prohibiciones inéditos hasta entonces. Para explicar los mecanismos de la censura, nos concentraremos en los procedimientos, los agentes y promotores de ésta y la defensa de la libertad de expresión realizada por la prensa obrera y utilizamos como fuentes la prensa obrera y moderna, los debates parlamentarios, los fallos judiciales y los archivos gubernamentales.
\end{abstract}

Palabras clave: Prensa obrera, Censura política, Libertad de expresión, Legislación

\begin{abstract}
In this article, the censorship against the Chilean working-class press in Chile between 1919 and 1925 will be analyzed in the context of the social question, the crisis of the oligarchy and the reconfiguration of the reppressive branch of the State. We consider as a hypothesis that governments favored the administrative-police censorship over judicial censorship, seeing the current legislation as insufficient in controling these media characterized as being "subversive". For this reason, in this time, it was built this way to create regulations that established controls and prohibitions unknown until then. To explain the censorship mechanics, we will focus on the procedures, agents and promoters of said censorship and the defense of freedom of expression carried out
\end{abstract}

\footnotetext{
* Chilena. Magíster en Historia. Investigadora Proyecto Fondecyt No. 1140122, dirigido por Verónica Valdivia Ortiz de Zárate. Agradezco a todo el equipo de investigación por los comentarios críticos y el apoyo con las fuentes para esta publicación y especialmente a Franchesca Aguilera. Contacto: kdonoso@gmail.com
} 
by the working-class press and we have used as sources the working-class and latest press, the parliamentary debate, the sentences, and the government files.

Keywords: Labor Press, Political censorship, Expression freedom

\section{INTRODUCCIÓN}

Este artículo, pretende abordar la censura a la prensa obrera entre 1919 y 1925 , periodo de alta conflictividad social y de crisis del orden oligárquico, cuyo desenlace fue la reconfiguración del Estado chileno a partir de la incorporación de límites a las libertades públicas, entre ellas, la de expresión. Estas restricciones fueron justificadas bajo el concepto de seguridad interior del Estado, calificando a los medios censurados como "subversivos" y por ello atentatorios a la integridad de la nación. Para abordar esta temática, analizaremos los diferentes mecanismos en que se manifestó la represión y censura a la prensa obrera, dando cuenta de los procedimientos, sus ejecutores y promotores, las lógicas políticas y penales bajo las cuales se llevaron a cabo y la posición de estos medios de comunicación frente a la libertad de expresión.

Para ello, utilizaremos el concepto de censura comprendido como política estatal, a partir de dos connotaciones fundamentales ${ }^{1}$. La primera es la censura previa, es decir, la implementación de mecanismos de control que intervienen en el proceso de creación del mensaje que se va a transmitir. Esto puede implicar, según la experiencia histórica, la instauración de una oficina de revisión de los mensajes que autoriza, a través de documentación, su publicación o transmisión, como fue el caso la Oficina de Prensa y Propaganda creada por el franquismo que supervisaba todos los impresos ${ }^{2}$ o la Jefatura Administrativa para la Publicación y el Comercio del Libro de la República Democrática Alemana que vigilaba la publicación de libros e intervenía en éstos sugiriendo cambios en palabras y redacción. ${ }^{3}$ Otra posibilidad era la designación de censores en las oficinas de las imprentas y/o redacciones quienes tenían la responsabilidad de revisar cada página de los documentos que se pretendiera publicar y dar su aprobación, rechazo absoluto o bien solicitar algunos cambios ${ }^{4}$. El segundo tipo de censura, se realiza con posterioridad a la publicación de un impreso, y tiene por objeto sancionar la transmisión de determinado

\footnotetext{
${ }^{1}$ Para explicar el concepto de censura, nos quedaremos con las medidas implementadas para el control de los medios impresos, sean estos libros, periódicos, revistas, etc. descartando en esta ocasión el debate sobre otro tipo de medios sonoros y audiovisuales.

2 Román Gubern, La Censura. Función política y ordenamiento jurídico bajo el franquismo. 1936-1975. Barcelona, Ediciones Península, 1981, p. 22 y ss.

${ }^{3}$ Robert Darnton, Censores trabajando. De cómo los Estados dieron forma a la literatura. México, Fondo de Cultura Económica: 2014, p. 147 y ss.

${ }^{4}$ Para el periodo de la dictadura militar chilena, el periodista Hernán Millas presentó a los censores en un ensayo lúdico donde cuestionaba la capacidad de estos funcionarios que poco comprendían de política, pues eran fundamentalmente personal del Ejército. En Hernán Millas, Los señores censores. Santiago, Editorial Antártica, 1985. En otros casos, como el descrito por Darnton para la RDA, los censores eran profesionales del área de literatura y militantes del Partido Comunista, por lo tanto, estaban preparados para cumplir esa función.
} 
mensaje, la que se produce generalmente a través de un proceso judicial. En la obra de Robert Darnton, el caso representativo de este tipo de censura es el de India bajo control británico, imperio que había proclamado la libertad de expresión en 1695 (erradicando la censura previa), pero como resguardo estableció los “juicios por difamación” los cuales caían contra los propagandistas de ideas contrarias al colonialismo ${ }^{5}$. Este caso es el más complejo de identificar y rastrear, pues no existe una institucionalidad dedicada a la censura de manera explícita. Además, es un tipo de censura disfrazado propio de los sistemas que publicitan el principio de la libertad de expresión, pero que impone sanciones para los abusos de aquella libertad ya sean en términos morales o políticos. Esta segunda forma de censura es la que encontramos en el caso que aquí presentamos, pues en todas las constituciones decimonónicas se consagró que en la república de Chile no habría censura previa, sin embargo, en sucesivos momentos, se han aplicado medidas restrictivas a la publicación de los impresos.

Según hemos estudiado para el periodo en cuestión, se llevaron a cabo

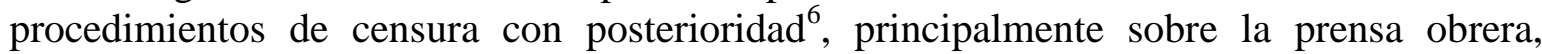
debido a que este movimiento logró consolidar su posición levantando sus propios medios de comunicación, los cuales fueron parte de su identidad organizacional y cumplieron un rol clave en el avance de su lucha y cuestionamiento del orden político y económico. Por ello, siendo la prensa obrera una plataforma de lucha social, el Estado a través de sus aparatos de orden y seguridad, determinó la necesidad de controlar la publicación de sus impresos, tarea para lo cual la legislación vigente -la Ley de Imprenta de 1872 y el Código Penal de 1874- resultó insuficiente. Así, la vía para realizar este tipo de censura fue de carácter policial-administrativo -y no judicial como en el caso expuesto por Darnton- y condujo al Estado y sus aparatos de seguridad a emplear mecanismos que estuvieron siempre al borde de la legalidad. De esta forma, la defensa de la libertad de expresión se convirtió en una bandera de lucha del movimiento obrero, poniendo en la agenda política el debate sobre los límites que debiera tener este derecho constitucional. Junto con lo anterior, sostenemos que, a raíz de este proceso, en 1925 las Fuerzas Armadas asumieron la tarea de crear una normativa que estableció mecanismos de control y penalización que afectó directamente la labor de la prensa obrera, representando las inquietudes de autoridades y tendencias políticas que defendían la restricción.

Como hemos señalado anteriormente, este artículo explora en un campo aún llano, ya sea desde la perspectiva de la libertad de expresión para la época como del desarrollo de la prensa obrera. Sobre esta última, cabe destacar que fue excluida como objeto de estudio en la primera historia de la prensa chilena escrita por Raúl Silva Castro ${ }^{7}$ y sólo en 1970 Osvaldo Arias logró saldar esa deuda realizando una exhaustiva antología de los periódicos considerados obreros, clasificándolos según su tendencia política y señalando que estos medios tienen como objetivo la propaganda de la lucha social en oposición a la prensa comercial movilizada por el lucro y la defensa del sistema ${ }^{8}$. Posteriormente, Eduardo Santa

\footnotetext{
${ }^{5}$ Darnton, Op. Cit., 95 y ss.

${ }^{6}$ Sólo en la década de 1930 se implementó la censura previa en Chile.

${ }^{7}$ Raul Silva Castro, Prensa y periodismo en Chile. 1812-1956. Santiago, Edit. Del Pacífico, 1958.

${ }^{8}$ Osvaldo Arias, La prensa obrera en Chile. 1900-1930. Chillán, Convenio CUT-UTE, 1970, p. 15.
} 
Cruz caracterizó a la prensa obrera como una expresión clasista y en "contestación al proceso de transformación de la prensa liberal en aparato ideológico del estado burgués"9 . También se abordó tangencialmente la historia de la prensa obrera en las historias del Partido Comunista, donde se ha resaltado la labor de Luis Emilio Recabarren como el gran fundador de este tipo de periódicos en todo el país ${ }^{10}$.

En los estudios de caso, se destaca el trabajo realizado por Jorge Rojas, quien investigó los periódicos Federación Obrera y Justicia de origen comunista, entregando importantes antecedentes de las ediciones y su contenido. A partir de aquellos, señaló que en el periodo 1920-1927 estos medios configuraron un proyecto alternativo a la prensa comercial o burguesa y desde ahí, disputaron la hegemonía política y cultural, haciendo un frente común con la prensa anarquista ${ }^{11}$. También aborda la represión señalando que en este periodo enfrentaron oleadas cíclicas de persecución policial y administrativa, a lo que se sumó la acción de grupos que asaltaban locales y destruían las instalaciones ${ }^{12}$. Asimismo, Víctor Muñoz realizó igual ejercicio con la prensa anarquista, concentrando su investigación en la relación de estos medios con el Estado, oscilante entre la tolerancia y el conflicto, y que fue predominante la tolerancia pues la represión se circunscribió a casos particulares. ${ }^{13}$ Antes de estos estudios, fue Ricardo Donoso quien abordó la temática de la libertad de expresión en su libro "Historia de las Ideas Políticas", en el cual rescató episodios conflictivos para el siglo XIX y comienzos del siglo XX, en el periodo previo al abordado en esta investigación ${ }^{14}$. Finalmente, sobre la ley de imprenta y su aplicación, encontramos sólo tesis de abogados en las cuales se da cuenta del cambio de carácter de esta legislación desde 1813 hasta $1925^{15}$.

${ }^{9}$ Eduardo Santa Cruz, Análisis histórico del periodismo chileno. Santiago, Nuestra América Ediciones, 1988, p. 52 .

${ }^{10}$ Hernán Ramírez Necochea, Origen y formación del Partido Comunista de Chile : ensayo de historia política y social de Chile. Moscú, Ed. Progreso: 1984. El socialista Julio César Jobet también reivindicó el rol del dirigente obrero, ver Recabarren y los orígenes del movimiento obrero y el socialismo chileno. Santiago, Ed. Prensa Latinoamericana S. A., 1973.

${ }^{11}$ Jorge Rojas, "La prensa obrera chilena: el caso de la Federación Obrera y Justicia. 1921-1927" en Olga Ulianova, Manuel Loyola y Rolando Alvarez, 1912-2012, El siglo de los comunistas chilenos. Santiago: Instituto de Estudios Avanzados, USACH, 2012, p. 71.

12 Ibíd., p. 66.

${ }^{13}$ Víctor Muñoz, “Cuando las bombas son de papel” Los trabajadores, el Estado y la propaganda anarquista impresa. Región chilena, 1915-1927” en Pacarina del Sur, Revista de Pensamiento Crítico Latinoamericano, Año 6, No. 22, enero-marzo 2015. Edición electrónica disponible en http://www.pacarinadelsur.com/home/huellas-y-voces/200-cuando-las-bombas-son-de-papel-los-trabajadoresel-estado-y-la-propaganda-anarquista-impresa-region-chilena-1915-1927 Algunas tesis también han dado cuenta de la prensa anarquista, Mónica Jaramillo [et. al.] "El Estado contra la prensa anarquista: el caso "Verba Roja" Tesis, Universidad de Santiago, 1997; Manuel Lagos, "Viva la anarquía: sociabilidad, vida y prácticas culturales anarquistas Santiago-Valparaíso, 1890-1927”, Tesis Magíster en Historia, Usach, 2009.

${ }^{14}$ Ricardo Donoso, Las ideas políticas en Chile, México, Fondo de Cultura Económica: 1946, cap. 9; para el siglo XX, La sátira política en Chile, Santiago, Imprenta Universitaria, 1950.

${ }^{15}$ Enrique Didier Silva, "De la libertad de imprenta", Memoria para optar al grado de Lic. En Facultad de Ciencias Jurídicas y Sociales, Universidad de Chile, 1933; Germán Orrego Vicuña, "Delitos de imprenta o de publicación", Memoria de prueba, Lic. En Ciencias Jurídicas Universidad de Chile, 1937; Raimundo de la Cruz, "La democracia y la libertad de prensa", Prensas de la Universidad de Chile, Santiago, 1940; Luis 
Para abordar esta investigación, hemos trabajado con la prensa como principal fuente para caracterizar las razones de la censura y el debate sobre la libertad de expresión, y complementamos con los Boletines de las Sesiones de Senadores. También acudimos a fuentes institucionales como la legislación y oficios del Ministerio del Interior, las Intendencias de Santiago, Iquique y Concepción para dar cuenta del procedimiento de la censura.

\section{EL MOVIMIENTO OBRERO Y SU PRENSA POLÍTICA.}

Hacia comienzos del siglo $\mathrm{XX}$, la prensa chilena vivió un profundo cambio producido por el abandono de la óptica ideológica y doctrinaria propia del siglo XIX, apareciendo una prensa moderna, orientada a la información y a crear un "mercado noticioso", "16 útil a la consolidación del capitalismo, difundiendo sus valores y principios. Liderada por El Mercurio (1900) y El Diario Ilustrado (1902) esta prensa habría integrado a los nacientes sectores medios en la redacción de los periódicos, naciendo el periodista "profesional", dedicado a reportear y difundir las noticias, de manera objetiva y con el fin de informar a la comunidad. Este proceso también implicó una diversificación de esta industria, la que desarrolló también revistas estilo magazine, las cuales abarcarían distintas temáticas de entretención, con dibujos y fotograbados, provocando una diversificación de los lectores ${ }^{17}$. Este segundo elemento permitió la integración de los sectores populares en tanto consumidores, conformándose una "compleja esfera pública plebeya" 18 , la cual estaba hegemonizada por medios masivos, con lenguaje directo, gran avisaje comercial, cuyo modelo estaba dado por el periódico El Chileno creado en 1892 y dedicado exclusivamente a un público de clase baja, adquiriendo el apodo de "el diario de las cocineras"19.

En este contexto irrumpió la prensa obrera con objetivos muy distintos de la prensa comercial y sus criterios de producción y venta tenían una orientación ideológica a favor de la lucha social ${ }^{20}$. Coincidiendo con el alza organizativa e ideológica del movimiento obrero, a partir de 1916 esta prensa creció sustantivamente hasta 1927, cuando fue aniquilada por la dictadura del general Ibáñez. ${ }^{21}$ Como primera característica podemos señalar que tanto para socialistas como anarquistas, la prensa era un pilar fundamental en la organización del movimiento obrero, razón por la cual insistían constantemente en crear periódicos, por muy pequeños que fueran, a través de los cuales se podían difundir ideas políticas, convocar a reuniones, encuentros culturales y mitines, y a la vez, se le daba existencia pública al

Aracena Aguayo, "Legislación y libertad de imprenta", Memoria para optar al grado de Lic. En Ciencias Jurídicas Universidad de Chile, 1953.

${ }^{16}$ Santa Cruz, Op. Cit., 35.

${ }^{17}$ Carlos Ossandón y Eduardo Santa Cruz, El estallido de las formas. Chile en los albores de la "cultura de masas". Santiago, Ed. Lom-ARCIS: 2005, pp. 35-37.

${ }^{18}$ Ibíd., 14.

${ }^{19}$ Ibíd., 113.

${ }^{20}$ Arias, Op. Cit. 15.

21 Peter DeShazo, Trabajadores industriales y sindicatos en Chile. 1902-1927, Santiago, Centro de Investigaciones Barros Arana, Dibam, 2007. pp. 215-216 y 287. 
movimiento en medio de una cultura principalmente letrada ${ }^{22}$. Por lo tanto, era fundamental conseguir una publicación, pero más aún lo era mantenerla en el tiempo lo que se conseguía con la adquisición de una imprenta, para tener autonomía en las publicaciones. Por ello, Luis Emilio Recabarren quien fuera reconocido por la creación de importantes periódicos de prensa obrera en el norte salitrero y en otras provincias del país, realizó sendas campañas para adquirir talleres y máquinas para estos medios ${ }^{23}$. Asimismo, la sección chilena de la IWW consiguió instalar sus maquinarias independientes en la capital e Iquique en $1923^{24}$, mientras que la Federación Obrera de Magallanes también contaba con sus talleres hacia 1920. En el caso de los anarquistas, fue más frecuente que simpatizantes o adherentes a este movimiento tuvieran pequeños talleres al servicio del movimiento, como fue el caso de Julio Valiente y Santiago Labarca, dueños de la Imprenta Numen ${ }^{25}$.

Una segunda característica corresponde a que la prensa obrera era esencialmente un medio de educación y propaganda política, que se producían junto a otras publicaciones escritas como los libros, folletos, afiches, volantes, entre otros. Los periódicos carecían de periodistas profesionales, y en su lugar se publicaban los escritos de colaboradores y redactores, los cuales entregaban las noticias relativas a la clase trabajadora pero también emitían artículos de opinión sobre determinados acontecimientos y de dirección del movimiento. De esta manera, la prensa, así como la imprenta misma, formaron parte de la cultura obrera, siendo un espacio de información alternativa a la oficial ${ }^{26}$. Los locales de las imprentas eran centros de reuniones y un núcleo noticioso, donde obtener información clave para el desarrollo de cualquier actividad del movimiento. Así, el local de la imprenta pasaba a integrar los círculos de sociabilidad obrera, imitando el modelo de la prensa comercial en cuyos locales también se transmitía información, sobre todo antes de la aparición de la radio. Y un tercer rasgo distintivo es que estos medios rechazaban el avisaje comercial como medio de obtener recursos y se financiaban con el aporte directo de los trabajadores, ya fuera a través de la compra del periódico o de donaciones voluntarias. Por ello, una de las principales dificultades que presentaron los medios de comunicación alternativos fue la falta de recursos, principal motivo de intermitencia o fin de los periódicos. A pesar de ello, la prensa obrera estuvo hasta el fin de esta época, negándose a la inclusión de publicidad, lo que generaba contratiempos y discusiones ${ }^{27}$.

\footnotetext{
${ }^{22}$ Según Arias, en el periodo 1916-1926 se fundaron 139 periódicos en total, siendo los de mayor duración El Despertar de los Trabajadores (Iquique, 1912-1927) y La Federación Obrera de Chile (Santiago, 1910-1922) cuya edición siguió siendo publicada bajo el nombre de Justicia (Santiago, 1922-1927). Ambos periódicos pertenecían a la órbita POS/PC, participando directamente en ellos Luis Emilio Recabarren, como director y creador de contenidos. En el caso de la prensa anarquista, los medios que lograron mayor tiempo de publicación fueron La Batalla (Santiago y Valparaíso, 1912-1926), Verba Roja (Valparaíso y Santiago, 19181927), Acción Directa (Santiago, 1920-1926) y El Surco (Iquique, 1917-1921). En Arias, Op. Cit., 61 a 125.

${ }^{23}$ Rojas, Op. Cit., 36

${ }^{24}$ Muñoz, Op. Cit.

${ }^{25}$ Ricardo Donoso, Alessandri, agitador y demoledor. Cincuenta años de historia política de Chile. Vol. I. México, Fondo de Cultura Económica: 1952, p. 255.

${ }^{26}$ Un análisis extenso de esta característica para el movimiento anarquista lo realiza Lagos, Op. Cit.

27 J. Rojas, Op. Cit., p. 54. Señala Rojas que la prensa comunista incorporó avisaje comercial de tiendas y talleres artesanales, rechazando la publicidad de las grandes tiendas, a diferencia de la prensa anarquista que
} 
A partir de estas características, sostenemos que estos medios de comunicación se transformaron en un importante elemento identitario del movimiento obrero y sus tendencias políticas. Desde esta perspectiva, tanto el sindicalismo, como el comunismo y el anarquismo visualizaban en la prensa un medio poderoso para la transformación social, ya fuera para la "educación libertaria" o para la "concientización en la lucha de clases", para llevar a cabo la acción directa o penetrar el sistema político. Por lo tanto, se transformaron en herederos de la cultura ilustrada decimonónica que consideraba la imprenta una llave del conocimiento y de la liberación ${ }^{28}$, pero con profundas diferencias dadas por sus principios ideológicos fundantes (crítica al sistema de dominación, crítica al patriotismo burgués, defensa de las garantías individuales, entre ellas el derecho de libertad de expresión) y por la práctica política (reuniones, mitines, marchas, manifestaciones callejeras, conferencias, jornadas educación popular/política, etc.). Ambos aspectos rompían con la cultura política tradicional y también con el papel que las elites le habían asignado a las clases trabajadoras.

\section{LA PRENSA OBRERA Y LA LIBERTAD DE EXPRESIÓN.}

Si bien desde los primeros ensayos constitucionales la libertad de prensa (como se comprendía la libertad de expresión) fue integrada como principio fundamental, sólo en el año 1872 los políticos e intelectuales liberales consiguieron crear una legislación que hiciera efectivo este derecho, ya que la carta fundamental de 1833 consagraba a todos los habitantes de la república: "la libertad de emitir, sin censura previa, sus opiniones de palabra o por escrito, por medio de la prensa o en cualquier otra forma" ${ }^{29}$, pero dejaba sujeto a una ley específica la calificación de "abusos" o "delitos" que pudieran cometerse en el ejercicio de este derecho ${ }^{30}$. Para resguardar la comisión de esos delitos, la ley de 1846 establecía límites políticos, burocráticos y económicos a la creación de imprentas e incluía como delitos la provocación a la rebelión o sedición, la desobediencia a las leyes y autoridades, la incitación a cometer cualquier acción calificada de delito, la apología del delito y la incitación al odio entre las diversas clases del Estado ${ }^{31}$. Estas limitaciones a la crítica política, afectaba directamente a los políticos liberales y su cuestionamiento al autoritarismo conservador, y por ello desarrollaron una serie de iniciativas para reformar esta legislación confiando en la libertad como principal herramienta para corregir los

nunca aceptó avisaje. Este hecho queda constatado en la editorial de Tribuna Libertaria, No. 29, enero de 1926.

${ }^{28}$ Bernardo Subercaseaux, Historia del libro en Chile (alma y cuerpo), Santiago, Ed. Lom, 2000, p. 51. Eduardo Devés, "La cultura obrera ilustrada chilena y algunas ideas en torno al sentido de nuestro quehacer historiográfico", Mapocho, Santiago, segundo semestre de 1991, №30, pp. 127-136

${ }^{29}$ Constitución Política de la República de Chile, 25 de mayo de 1833, Art. 10, inciso 3. Disponible en http://bcn.cl/1m3sn (consultada el 15 marzo 2015)

${ }^{30}$ Donoso (1946) Op. Cit., 355-359 y 361-366

${ }^{31}$ Ley sobre abusos de libertad de imprenta, 16 de septiembre 1846, Título I. En Ricardo Anguita, Leyes publicadas en Chile desde 1810 hasta el 1 de junio de 1912. Santiago, Imprenta Barcelona, 1912, p. 478. 
abusos de imprenta, eliminando los castigos y penas y apelando al debate político ${ }^{32}$. Esta reforma se consiguió finalmente en 1872, con un consenso amplio en el Congreso en el cual se descartó considerar delito de imprenta la provocación o llamado a "sedición" o "rebelión", a pesar de la resistencia conservadora ${ }^{33}$. La ley consideró sólo "abusos" de imprenta los ultrajes a la moral pública y religión del Estado; el menoscabo del crédito o buen concepto de un empleado público o de una persona particular ${ }^{34}$. También se determinó que los abusos de imprenta serían juzgados por un jurado creado especialmente para cada caso y se consideraron tres grados de abuso, los que serían sancionados con multas en dinero, descartando el presidio. Se establecía que los dueños de imprenta eran responsables de las publicaciones, salvo que se presentara el autor del escrito o publicación, y debían incluir en cada trabajo el nombre de la imprenta, lugar y fecha de edición; a la vez que el dueño de la imprenta debía entregar al acusador público de la provincia respectiva, un ejemplar de los impresos al mismo tiempo de su publicación, dos a la Biblioteca Nacional, uno a la Secretaría de la Intendencia o gobierno departamental, y enviar uno al Ministerio del Interior. Además, se posicionó en una actitud de defensa de los escritos de carácter científico y literario, blindándolos de toda acusación inquisitoria ${ }^{35}$. Con todo, la ley de 1872 recuperaba el espíritu liberal de las primeras legislaciones promulgadas en 1813 por José Miguel Carrera y en 1828 por Aníbal Pinto ${ }^{36}$.

Es importante señalar que dos años más tarde se promulgó el Código Penal, en el cual se incluyeron como "Delitos contra la seguridad interior del Estado" el alzamiento a mano armada contra el gobierno, el inducir a los alzados o promover la sublevación, seducir a las tropas o usurparan el mando de ellas entre otras. Sin embargo, en ninguno de estos delitos se precisó el papel de la imprenta o de la prensa en ellos, por el contrario, el Título III del Código Penal, Artículo 137, se determinó que "los delitos por libre ejercicio del sufragio y la libertad de emitir opiniones por la prensa se penan por leyes de sufragio e imprenta" 37 .

Este era el marco legal en el cual se desenvolvió el movimiento obrero, proclive al ejercicio de la crítica política a través de la prensa, sin penalización ni sanción alguna. Además, el carácter de ambas legislaciones, sumado al acceso a los medios modernos de imprenta, provocó el crecimiento exponencial de los talleres de imprenta a fines del siglo XIX en el país. A partir de los datos del censo, Bernardo Subercaseaux señaló que el número de tipógrafos en todo el país se extendió de 380 en 1865 a 1.223 en $1895^{38}$. En el mismo año, existían 29 imprentas en Santiago, 22 en Valparaíso y 7 en Concepción y

\footnotetext{
32 José Victorino Lastarria, Proyecto de libertad de imprenta presentado al Congreso Nacional, Santiago, Imprenta del Progreso, 1849, p. 12. Disponible en http://www.memoriachilena.cl/602/w3-article-86272.html (consultado el 20 de marzo 2015)

${ }^{33}$ Sesión $13^{\mathrm{a}}$, 5 de julio 1872, en Cámara de Senadores, Boletín de Sesiones Ordinarias 1872. Imprenta Nacional, 1872, p. 62.

${ }^{34}$ Ley sobre Abusos de la Libertad de Imprenta, 17 de julio 1872, Art. $3^{\circ}$ disponible en http://bcn.cl/1tr0v (consultado el 20 de marzo 2015)

${ }^{35}$ Ibíd, Artículo 6․

${ }^{36}$ Orrego, Op. Cit., p. 87.

${ }^{37}$ Código Penal de la República de Chile, Santiago, Imprenta de la República,1874, p. 65.

${ }^{38}$ Subercaseaux, Op. Cit., 52 y 81.
} 
además se produjo la diversificación y ampliación de la industria impresora, la cual dedicaba su trabajo a grupos sociales específicos, apareciendo por primera vez prensa y literatura orientada a los sectores populares ${ }^{39}$. A su vez, el aumento descontrolado de los medios de comunicación impresos y la libertad de acción que dejaba este marco legal, provocó cuestionamientos desde un sector de la clase política que evaluaba negativamente su impacto en el debate político, y consideraban que se debía incluir como delitos las ofensas y ataques a los funcionarios públicos y la incitación a la sedición o revuelta ${ }^{40}$. Todos estos proyectos naufragaron en ambas cámaras del Congreso y sólo en 1914 se ingresó una modificación al artículo 38 de la ley de imprenta, que aumentó a tres los ejemplares que se entregaban a la Biblioteca Nacional ${ }^{41}$. Los fundamentos para sugerir reformas se amparaban en el contexto político, pretendiendo contener las ácidas críticas sobre los funcionarios públicos que se realizaban desde la prensa seria hasta la más satírica $^{42}$. Asimismo, el énfasis de la reforma legal impulsado por Barros Errázuriz en 1907 ocurrió a sólo días de producida la gran huelga de Iquique cuyo desenlace fue la matanza de más de mil obreros en la Escuela de Santa María, escondiendo tras el proyecto el interés por silenciar las críticas al gobierno y al mando militar, desde la prensa obrera y de oposición. Por su parte, la prensa obrera, tomó la posta de la reivindicación de la libertad de expresión defendida en el siglo XIX por los liberales. Según Eduardo Santa Cruz, esto se debió a que en el nuevo contexto el pensamiento liberal ya no representaba un factor de cambio histórico, sino de mantención del statu quo ${ }^{43}$. Según lo que hemos visto en la prensa del período, para la elite, el tema de la libertad de expresión estaba separada de la penalización de las publicaciones consideradas "amenazas subversivas", pues los procesos judiciales no implicaban violación de dicha libertad, sino por el contrario, implicaba la defensa de ésta. Es decir, que las publicaciones subversivas atentaban contra la libertad de expresión y la seguridad del Estado y no eran parte del ejercicio de ese derecho ${ }^{44}$. Esta argumentación, utilizada también por el Estado, era una manera de invalidar a la prensa obrera como interlocutor y marginarla incluso de la posibilidad de obtener derechos. Con ello, se levantaron nuevamente voces que señalaban que la ley de imprenta era insuficiente

\footnotetext{
${ }^{39}$ Ibíd., 102.

${ }^{40}$ El 27 de diciembre de 1907 el diputado Alfredo Barros Errázuriz (Partido Conservador) presentó una moción de reforma de la ley de imprenta que reunió los proyectos presentados anteriormente por Eduardo Videla y Juan Enrique Tocornal en 1892, por Carlos Palacios en 1894, por Ramón Bañados, Francisco Javier Concha y Jorge Hunneus en 1901, y por el senador Carlos Walker Martínez en 1905. Ver el texto de Orrego, Op. Cit., 89.

${ }^{41}$ De la Cruz, Op. Cit., 19.

${ }^{42}$ Donoso (1950), Op. Cit., 136

${ }^{43}$ Santa Cruz, Op. Cit., 43-44.

44 “Caídos en poder de la justicia los cuatro agitadores en cuestión, pretendieron acogerse a la ley de imprenta para evitar la represión de sus delitos, como si la campaña maximalista en que están empeñados no hubiera tenido otra tribuna que la del pasquín que dirigen. Los agitadores, sin embargo, eran demasiado conocidos y sus esfuerzos para incitar al pueblo en contra de la autoridad constituida, en mitines y reuniones, eran demasiado notorios, para que el poder judicial se dejara engañar con el fútil pretexte de que los delitos comunes por ellos cometidos, y sancionados por el Código Penal, perdían su carácter de tales por no estar comprendidos en la ley de imprenta", en "En defensa del anarquismo", El Diario Ilustrado, Santiago, 4 de diciembre 1919, p. 3.
} 
para contener las ideas anarquistas y comunistas, las cuales no debían estar protegidas bajo legislación alguna.

Así, la prensa obrera, cuestionaba la ambivalencia de la prensa "burguesa", la cual defendía la libertad de expresión pero no se manifestaba cuando la censura caía sobre ellos $^{45}$. Asimismo, los medios populares denunciaron y criticaron crudamente el accionar de los aparatos de seguridad del Estado, amparándose siempre en el derecho constitucional de libertad de expresión. Es significativo que los representantes del movimiento obrero, incluso el más revolucionario como el anarquista, se ampararon en las leyes del Estado para cuestionar las agresiones de la autoridad, produciéndose la "apropiación de los derechos ciudadanos"46. Así lo manifestó en más de una ocasión el periódico de la Federación Obrera de Chile "hacemos uso de un derecho público, consagrado en los Códigos cual es el de emitir nuestros pensamientos que nacen al calor de una ambición de mayores libertades en favor de los que sufren opresión y son obligados por la fuerza organizada de la clase dominante, a hacer la voluntad ajena". ${ }^{47}$ El mismo argumento del amparo de la libertad de expresión fue utilizado por algunos dirigentes anarquistas, como Armando Triviño, quien al ser entrevistado mientras se encontraba esperando audiencia con un juez precisamente tras haber sido detenido por publicar un escrito anti-militarista, señaló que "lo que hace la justicia burguesa... es un atentado contra la libertad de pensamiento que tenemos todos los ciudadanos. Nosotros no somos subversivos ni sediciosos, como dicen: divulgamos nuestras ideas y nada más ${ }^{48}$.

Otro argumento utilizado fue la calificación de la ley como antojadiza y "burguesa" al no ser igualitaria a todas las clases y movimientos sociales. Los socialistas señalaban que la libertad de imprenta, sólo estaba vigente para quienes opinaban de acuerdo con el gobierno y alaban sus actos, no para quienes lo criticaban, "en cambio escribir pensamientos opuestos a los dominantes para ver destruida la imprenta en donde se publicasen, para ser agredido por un matón cualquiera y en muchos casos para ir a parar al presidio por subversivo (...) Tales son las libertades, éstas las garantías que nos ofrecen las legislaciones burguesas" ${ }^{\prime 9}$. Esa desigualdad en la aplicación de la ley fue denunciada de manera constante por Recabarren, quien señaló que la libertad no existía para los trabajadores ni para los socialistas ${ }^{50}$ : "En Chile hubo libertad cuando nadie la necesitaba; pero apenas la masa adquirió el primer rudimento de cultura, la libertad sufrió la primera limitación" 51 . Otro rol defendido por la prensa obrera, era el de ser "fiscalizadores" de los

\footnotetext{
45 “Atentado Dinamitero a "La Patria”, El Despertar de los Trabajadores, Iquique, 27 de enero 1921.

${ }^{46}$ Verónica Valdivia “Los tengo plenamente identificados' Seguridad interna y control social en Chile. 19181925", (manuscrito inédito).

47 "Golpe de Autoridad" La Federación Obrera de Chile, Santiago, 9 de diciembre 1921, p. 1.

48 “Otra vez los anarquistas", Revista Zig Zag, Santiago, 27 de marzo 1920. Citado en Víctor Muñoz, Armando Triviño: wobblie. Hombres, ideas y problemas del anarquismo en los años 20. Santiago, Ed. Quimantú, 2009, p. 23.

49 "Los derechos y las libertades en las legislaciones capitalistas". El Despertar de los Trabajadores, Iquique, 3 de enero 1922.

50 "Carta de Luis Emilio Recabarren al Prefecto de Policía de Antofagasta”, Archivo Ministerio del Interior, Vol. 5190, 1919.

51 “El Gabinete contra la libertad”, El Despertar de los Trabajadores, Iquique, 17 de febrero de 1922
} 
actos del gobierno, apelando al viejo argumento liberal que sólo con una prensa libre se evitan y controlan los abusos de la burocracia estatal: "Nosotros estamos hartos de soportar esta odiosa dependencia, porque la clase dirigente demuestra todos los días que no sabe gobernar digna e inteligentemente. No merece pues, obrar sin un control que le corresponde ejercer al pueblo día a día más capaz y culto" 52

Estos argumentos, que son fundamentalmente liberales y republicanos, fueron complementados con la fuerza de la ideología, pues el derecho a manifestarse públicamente lo daba la certeza de la razón. Así lo expone Armando Triviño, en numerosos artículos donde señala que es deber de todo anarquista llevar a cabo la "guerra de ideas", lo que se reafirmaba tras cada allanamiento, detención y destrucción de las imprentas: "el anarquista que se respeta a sí mismo y respeta a los demás, debe combatir, ser intolerante para con aquellos conceptos irracionales que son una amenaza permanente para su vida, y exponer las doctrinas que se imponen por lógica, por su bondad, y por su fuerza de progreso"53. Por lo tanto, la represión era un golpe esperado y resistido, frente al cual debían levantarse las veces que fueran necesarias: "Nada nos amordazará para callar una sola palabra de lo que sabemos de esta trama tenebrosa y anárquica, que enmascarada bajo el disfraz del orden y agitando los sonoros cascabeles de la paz social se desencadenó contra lo que en Chile hay de más noble, puro y alto: las agrupaciones obreras y estudiantiles"54.

Con la misma convicción, se pronunció en más de una ocasión Luis Emilio Recabarren, negando el apelativo de "subversivo", fundamentalmente porque las reformas a las que aspiraba el socialismo debían realizarse por la vía institucional. Pero también asumía que la labor del militante era la propaganda, a pesar de las represalias que el Estado tomaba en su contra, pues según Recabarren "un ideal que no se practica, es un ideal muerto",55.

De esta manera, si bien el movimiento obrero y sus representaciones políticas retomaron los argumentos liberales para defender el legítimo derecho a difundir sus ideas, más importante era la certeza de la razón de su pensamiento y la posibilidad de transformar la realidad. Como señalamos anteriormente, para ese voluntarismo la propaganda en general y la prensa en particular, cumplía un papel fundamental en la difusión del pensamiento revolucionario y en generar una nueva conducta entre los trabajadores. Por ello, a pesar de las constantes medidas represivas, pertinazmente los dirigentes y redactores insistían en la necesidad de la publicación del medio y de la transmisión de éste, burlando incluso las prohibiciones. El derecho y la razón serían las herramientas con que la prensa obrera se defendería de la represión.

\footnotetext{
52 "Golpe de Autoridad” La Federación Obrera de Chile, Santiago, 9 de diciembre 1921, p. 1.

${ }^{53}$ El Sembrador, Iquique, 8 de marzo 1924. En Víctor Muñoz, Armando Triviño... Op. Cit., p. 117.

54 "Nuestra palabra de ayer" Juventud, Santiago, Nro. 11-12, enero-febrero-marzo de 1921, p. 5.

55 El Socialista, Antofagasta, 30 de enero 1919. En Julio Pinto, Luis Emilio Recabarren. Una biografía histórica, Santiago, Ed. Lom, 2013, p. 179.
} 


\section{LOS MECANISMOS DE LA REPRESIÓN A LA PRENSA OBRERA.}

En esta sección explicaremos cómo operaron los mecanismos del silenciamiento de la prensa política popular, los cuales oscilaron entre formas legales e ilegales, frontera difícil de delimitar para los funcionarios encargados de acosar a los dirigentes y representantes políticos adversos al sistema de gobierno imperante. Como hemos mencionado anteriormente, el tipo de censura aplicada en este periodo corresponde a la realizada con posterioridad a la publicación de los impresos, pues no existió hasta 1925 un mecanismo de censura previa. Por lo tanto, el formato transversal utilizado fue sancionar por medio de un proceso judicial, o al menos, a través del intento por abrir un juicio contra una imprenta o contra el director o autor de un escrito. Lo que se buscaba era "castigar" a los autores del impreso para evitar la publicación de nuevos documentos, y por otro lado se buscaba amedrentar, a través de la destrucción o atentado contra una imprenta. Para analizar este proceso hemos dividido el periodo en tres etapas cronológicas.

\subsection{La Ofensiva de Sanfuentes: 1918-1920.}

Para este periodo, hemos identificado tres estrategias de censura de prensa, las cuales funcionaron entramadamente. La primera corresponde a los allanamientos de imprentas realizados bajo orden judicial con la finalidad de buscar pruebas para un proceso, pero que involucró la destrucción de los talleres allanados. La segunda se refiere a los ataques por grupos de civiles a las oficinas de imprenta o locales, los cuales en la mayoría de los casos fueron con la complicidad de la policía e incluso de las Fuerzas Armadas. Y el tercer mecanismo consistió en la apertura de procesos judiciales contra redactores y directores de periódicos, lo que implicó largas detenciones y juicios, muchos de los cuales se iniciaron a partir de una denuncia de la Intendencia o de las investigaciones policiales. Como vemos, en los tres mecanismos tuvo un papel importante la Policía, la cual contaba con un aparato de seguridad creado en el siglo XIX y el que si bien tenía como finalidad "perseguir y aprehender a los delincuentes y practicar las gestiones que tiendan al esclarecimiento de los juicios" ", ya entrado el siglo XX adquirió además facultades de investigación del movimiento obrero y sus corrientes políticas ${ }^{57}$. Para colaborar en esta tarea, se incorporó el trabajo de agentes encubiertos, los cuales se infiltraban en reuniones sindicales, anarquistas, socialistas y comunistas, así como en los mitines callejeros, elaborando informes con los nombres de quienes intervenían en las reuniones, describiendo el tenor de sus discursos, la reacción de los auditores y enfatizando si hubo o no proclamas revolucionarias. El Archivo de la Intendencia de Santiago se encuentra plagado de estos informes los cuales se realizaban siempre sin firma al pie, y dirigidos al Sub-prefecto o Prefecto de la Policía, y en varias ocasiones se insertaban ejemplares de periódicos, folletos

\footnotetext{
${ }^{56}$ Waldo Urzúa, Del pesquisa al investigador. Santiago, Talleres Gráficos La Nación, 1947, p. 8.

${ }^{57}$ Gonzalo Rojas y Jorge Rojas, "En búsqueda de una definición: notas para el estudio de la policía y los trabajadores durante el gobierno de Alessandri (1920-1924)", Boletín de Historia y Geografía. Instituto de Estudios Superiores Blas Cañas, No. 14, 1998, p. 285.
} 
o volantes repartidos en la actividad, destacando la presencia o ausencia de consignas subversivas o revolucionarias ${ }^{58}$.

Esta tarea, que era fundamentalmente informativa, resultaba clave para la segunda labor que consistía en el levantamiento de pruebas para la apertura de los procesos judiciales. Para ello, la policía realizaba espectaculares allanamientos a las imprentas, los cuales generalmente implicaban la destrucción del inmueble y de los ejemplares de propaganda escrita encontrados en el taller. Considerando el procedimiento, estas acciones no eran legales. El allanamiento buscaba amedrentar, lo cual no estaba explícito en el proceso judicial, pero sí funcionaba implícitamente $\mathrm{y}$, sobre todo, como experiencia represiva 59 . A pesar de la "ilegalidad" en la que pudiera caer este accionar, consideramos que lo fundamental es que poco a poco se fue instalando una práctica de la persecución política que si bien no era efectiva para conseguir una penalización, sí lo era en establecer un sistema de espionaje político invisible que amainara las manifestaciones populares.

Para analizar este proceso, utilizamos como primer referente la promulgación de la Ley de Residencia, en diciembre de 1918, que autorizó al Ejecutivo, a través de la Intendencia, a expulsar a extranjeros del país, por razones políticas y morales sin pasar por un juicio $^{60}$. Esta legislación, permitió el marco de acción para sancionar actos cometidos a través de la imprenta, pero sólo a extranjeros, lo que apareció especificado en el artículo $2^{\circ}$ que prohibía la entrada al país de extranjeros que "practicaran o enseñaran la alteración del orden social o político por medio de la violencia", que propagaran doctrinas que se consideraban incompatibles con la unidad nacional, los que provocaran manifestaciones contra el orden establecido y quienes desarrollaran actividades atentatorias a la moral y las buenas costumbres ${ }^{61}$.

Como hemos señalado, para los nacionales no existía una legislación vigente que sancionara la propaganda o difusión de doctrinas "contrarias al orden" y/o a la "Nación", pero sí se estableció esta condición para los extranjeros, cuyo cumplimiento implicaba el espionaje policial y la voluntad de la Intendencia. Los casos más emblemáticos fueron el de los ciudadanos españoles Casimiro Barrios y Manuel Peña. El primero de ellos fue acusado de propagar doctrinas incompatibles con la individualidad de la nación ${ }^{62}$ para lo cual se usó como evidencia unos folletos repartidos en una campaña contra el Ejército. Barrios finalmente logró revocar su expulsión, pero no fue así el caso de Peña expulsado en abril de

\footnotetext{
${ }^{58}$ Archivo Nacional, Fondo Intendencia de Santiago, Volúmenes 470, 483, 484, 485, 486, 501, 502, 526, 527, 531, 532, 540 y 542, comprenden los años 1918 a 1923.

${ }^{59}$ Camilo Plaza ha determinado que el accionar de la policía se realizaba en torno a un "cheque en gris", es decir, que tras recibir la orden para realizar determinada acción, el criterio aplicado para actuar dependía de los ejecutantes, pues no estaba contenido en indicación ni ley alguna. En Camilo Plaza, "Organismos fundamentales del Estado: la función político-policial de la Dirección General de Investigaciones. 19331948”, Tesis para optar al grado de Magíster en Historia, Universidad de Santiago de Chile, 2015.

${ }^{60}$ Camilo Plaza y Víctor Muñoz, "La ley de Residencia de 1918 y la persecución a los extranjeros subversivos", Revista de Derechos Fundamentales, Universidad del Mar, No. 10, 2013, pp. 107-136; Verónica Valdivia, Op. Cit.

${ }^{61}$ Ministerio del Interior, Ley núm. 3446 que impide la entrada al país o la residencia en él de elementos indeseables, 12 de diciembre 1918. Disponible en http://bcn.cl/1qke6 (consultada el 11 de junio de 2014)

62 "Sentencia No. 643: Casimiro Barrios", La Gaceta de los Tribunales. Vol. 5: Noviembre y diciembre 1918. Santiago, Dirección General de Talleres Fiscales de Prisiones: 1925, p. 1889.
} 
1920, por "vender y donar en su establecimiento libros, folletos y periódicos de doctrinas anarquistas, que persiguen la destrucción del régimen de gobierno, de la constitución de la familia y del derecho de propiedad por medio de la violencia"63. En ambos casos, implicaron represión a la transmisión de los impresos y no a la autoría ni emisión de ellos. En el caso de Peña se señala en el informe de la Intendencia como una de las evidencias el hecho que "en diversas ocasiones se haya negado a retirar las susodichas obras de sus vidrieras, requerido por la policía", y además, que las vendía "a precios voluntarios algunos de estos impresos y repartiendo gratis otros a los obreros y soldados" ${ }^{\text {" }}$ argumentos utilizados como agravante de la falta que era la venta de literatura anarquista, dando un precedente de la ilegalización de este movimiento.

Para los nacionales, en tanto, el ciclo represivo se inició los primeros días de enero de 1919, en el contexto de la preparación de una segunda marcha de la Asamblea Obrera de Alimentación Nacional (AOAN), la cual ya había realizado multitudinarios mítines tras la demanda por medidas para contener el alza del costo de la vida, y que habían paralizado las grandes ciudades. Si bien el gobierno solicitó Facultades Extraordinarias para el Presidente de la República, que permitía declarar Estado de Sitio en determinados puntos del país y suspender o restringir el derecho de reunión y la libertad de imprenta ${ }^{65}$, antes de ello ya se habían producido detenciones y censura de prensa en el norte del país y en Santiago y Valparaíso. En enero de 1919 fueron asaltadas las imprentas de los periódicos El Surco (anarquista) y El Despertar de los Trabajadores (del Partido Obrero Socialista) en Iquique, bajo el argumento de ser "publicaciones antipatrióticas". En el caso de El Surco, el resultado del asalto y allanamiento fue la detención de su equipo editorial y el requisamiento de la imprenta hasta agosto de ese año ${ }^{66}$. En el caso de la imprenta socialista, desde el mismo diario se aseguró que la turba fue dirigida por oficiales del ejército, quienes destruyeron con martillos y combos el inmobiliario y las máquinas de la imprenta, amarraron a las mujeres y golpearon a los socialistas que estaban en el lugar ${ }^{67}$. Frente a estas acusaciones, el Intendente de Tarapacá negó toda participación señalando que la destrucción de los talleres socialistas se produjo por "móviles políticos o de otro orden, ajeno en absoluto a la acción de las autoridades o de las instituciones armadas y policía", pero se mostró optimista pues esta acción y el requisamiento de El Surco, "ha eliminado dos medios importantes de propaganda subversiva y revolucionaria que mucho mal ha hecho entre las clases y gremios obreros de la pampa, especialmente"

\footnotetext{
63 “Sentencia No. 53: Contra Manuel Peña” en La Gaceta de los Tribunales. Primer Semestre, 1920. Santiago, Imprenta Balcells: 1926, p. 299.

${ }^{64}$ Idem.

${ }^{65}$ Ministerio del Interior, Ley No. 3494, que otorga al presidente de la República facultades para restringir ciertas libertades, 6 de febrero 1919. Disponible en http://bcn.cl/1ql17 (consultada el 12 de junio de 2014).

${ }^{66}$ Manuel Lagos, Los Subversivos. Las maquinaciones del poder. "República” de Chile, 1920. Santiago, Ed. Quimantú, 2012, p. 19.

${ }^{67}$ Sesión $61^{\text {a }}$ extraordinaria, 3 de febrero 1919, en Cámara de Senadores, Boletín de Sesiones Extraordinarias, 1918-1919, Imprenta Nacional, 1919, p. 1477.

${ }^{68}$ Archivo Nacional de la Administración, Fondo Ministerio del Interior. Vol. 5074 Antecedentes oficios enviados. Iquique, 28 de enero de 1919.
} 
En el mismo periodo, en Antofagasta también se produjeron asaltos a los diarios $L a$ Nación y El Socialista, con la misma escena: destrucción de material de imprenta y detención de sus trabajadores ${ }^{69}$. Según la denuncia realizada por el senador demócrata Malaquías Concha, el Comandante de Armas General Rojas Arancibia inició una persecución contra los dirigentes obreros reconocidos como Luis Emilio Recabarren, José Santos Córdova y Mariano Rivas, y también clausuró el local demócrata "Casa del Pueblo" el día 26 de enero 1919 y se incautaron, sin orden judicial, los ejemplares del periódico La Nación de esa ciudad ${ }^{70}$.

En Santiago, en la misma fecha, la policía incautó la imprenta del periódico demócrata El Comercial y sustrajo los ejemplares de una edición ${ }^{71}$. La razón sería que el periódico reprodujo el discurso emitido por el diputado Nolasco Cárdenas en noviembre de 1918 en la Cámara de Diputados, el que provocó controversias por ser calificado de antipatriota, al señalar que las clases trabajadoras no responderían como antes al llamado a la guerra porque estaban conscientes de que había problemas más urgentes que resolver ${ }^{72}$.

De esta oleada, el único proceso judicial abierto fue contra Celedonio Arenas, como director de El Surco, inculpado por la publicación de una noticia sobre el accionar de las Ligas Patrióticas contra los peruanos residentes en Tacna y Arica. También resultaron detenidos otros tres anarquistas pertenecientes al Centro de Estudios Sociales "La Brecha", Ramón Rusyñol, J. Quezada y Guillermo Toledo ${ }^{73}$. La defensa de Arenas, apeló a la libertad de expresión y a la imposibilidad de aplicar la ley de imprenta, pues no correspondía a la justicia ordinaria procesar por este código, sino que debía levantarse un “jurado de imprenta". Frente a esta dificultad legal, el periódico conservador El Diario Ilustrado señaló:

Caídos en poder la justicia los cuatro agitadores en cuestión, pretendieron acogerse a la ley de imprenta para evitar la represión de sus delitos, como si la campaña maximalista en que están empeñados no hubiera tenido otra tribuna que la del pasquín que dirigen. Los agitadores, sin embargo, eran demasiado conocidos y sus esfuerzos para incitar al pueblo en contra de la autoridad constituida, en mitines y reuniones, eran demasiado notorios, para que el poder judicial se dejara engañar con el fútil pretexte de que los delitos comunes por ellos cometidos, y sancionados por el Código Penal, perdían su carácter de tales por no estar comprendidos en la ley de imprenta $^{74}$.

En ese entonces se encontraba también detenido el anarquista Julio Rebosio, director del periódico quincenal Verba Roja, de Valparaíso. Había sido apresado por la policía en diciembre de 1918, acusado de "subversivo, remiso, desertor" y de "espía

\footnotetext{
69 "El terror del Sable”, Verba Roja, Santiago, No. 6, 1ª quincena de febrero 1919

${ }^{70}$ Sesión $61^{\text {a }}$ extraordinaria, 3 de febrero 1919, en Cámara de Senadores, Boletín de Sesiones Extraordinarias, 1918-1919, Imprenta Nacional, 1919, p. 1477.

71 Ídem.

72 Sesión 28 extraordinaria, 25 de noviembre 1918. Cámara de Diputados, Boletín de Sesiones Extraordinarias 1918-1919, Imprenta Nacional, 1919, p. 661.

${ }^{73}$ Lagos (2012) Op. Cit., p. 19.

74 “En defensa del anarquismo", El Diario Ilustrado, 4 de diciembre 1919, p. 3
} 
peruano" y como prueba se utilizaron dos artículos de la revista que aún no salían en circulación $^{75}$. A pesar de estas acusaciones, el juez a cargo determinó que no había pruebas suficientes; pero en lugar de ser liberado, fue nuevamente procesado por una causa pendiente por deserción. Estando Rebosio en prisión, Verba Roja siguió su publicación, alojándose desde julio de 1919 en Santiago, en la Imprenta Numen, de propiedad de Julio Valiente, la que fue allanada a fines de agosto, en la búsqueda de pruebas para abrir proceso judicial contra los directores por el artículo "El Soldado". Este escrito hacía una interpelación directa a los militares, a no usar las armas contra la clase obrera, y cuestionaba el sentido del patriotismo ${ }^{76}$.

Según la versión entregada en la misma revista, el jefe de los policías consideró subversivo el artículo y que "incitaba a los soldados a desertar"; en tanto que para Verba Roja sólo instigaban a los soldados a "pensar y deliberar" y eso no era delito. El tema del antimilitarismo, en el contexto de conflicto-tensión con Perú por las provincias cautivas, era foco de atención de la sección investigaciones de la policía. En el procedimiento, y como se iría haciendo costumbre, la policía intentó destruir las máquinas de la imprenta, requisó los ejemplares de la revista publicados en los meses de julio y agosto y detuvo al administrador del periódico Manuel Silva. El redactor de los artículos cuestionados, Armando Triviño, alcanzó a huir y estuvo prófugo por algunos meses, pero luego fue detenido y se sumó como acusado en esta causa ${ }^{77}$.

La defensa de los anarquistas, realizada por el abogado Carlos Vicuña, nuevamente apuntó al procedimiento, pues no era la justicia ordinaria la encargada de procesar ni dirimir sobre temas relativos a los escritos, sino que debía aplicarse el proceso indicado en la ley de imprenta y por lo tanto este proceso carecía de legalidad. Vicuña consiguió que tanto Silva como Triviño salieran en libertad bajo fianza en noviembre de $1919^{78}$, y el proceso judicial quedó inconcluso. En el mes siguiente, sería nuevamente el turno de $E l$ Surco y Celedonio Arenas, detenido esta vez por la publicación de noticias sobre el conflicto ferroviario, donde se llamaba a los obreros a sabotear a la empresa si ésta no cumplía los compromisos establecidos con los trabajadores y se criticaba el accionar represivo del Ejército en las huelgas ${ }^{79}$. En este caso y considerando los reveses de los procesos anteriores, la estrategia judicial que se utilizó fue procesar por infracciones al Código Penal. Sobre esto, la sentencia en primera instancia contra Arenas, señala lo siguiente:

\footnotetext{
${ }^{75}$ Víctor Muñoz, “Oro peruano y represión obrera: Los últimos días del anarquista Julio Rebosio Barrera” en http://www.anarkismo.net/article/11948 [consultado el 29 de mayo de 2015]

76 "Hay que arrojar esa venda, hay que ver claro, hay que reflexionar, hay que distinguir dónde está el enemigo y combatirlo, frente a frente, a pecho descubierto. Sólo así se es valiente, se es héroe. ¿Es el pueblo enemigo del soldado? ¿Son los trabajadores enemigos de esta tierra? No, los trabajadores aman la tierra que trabajan y odian a los que viven de sus frutos sin trabajar. Si el patriotismo tiene algún significado". "El Soldado", Verba Roja, Santiago, Segunda quincena de agosto 1919, p. 1.

${ }^{77}$ Jaramillo [et. al.] Op. Cit., pp. 200-203.

${ }^{78}$ Ibíd., p. 208.

79 “El Surco contra la justicia”, El Surco, Iquique, 25 de diciembre 1919.
} 
(...) $3^{\circ}$ Que la circunstancia de incitar por medio de la imprenta a la destrucción del Estado o de la propiedad particular, como la propaganda contra las buenas costumbres, contra la lei y orden público y la intimación a los Tribunales de Justicia por los fallos pronunciados y la instigación al saqueo y al incendio, no son manifestaciones de opinión sino que constituyen la perpetración de delitos previstos y penados en nuestra legislación penal"

$4^{\circ}$ Que la imprenta en tales casos es el medio o instrumento de que se sirve la persona para cometer estas infracciones legales y la dedicación permanente a ello constituye un trabajo o industria contraria a las buenas costumbres, a la seguridad y salubridad pública que es prohibida por la Constitución de la República"80.

Arenas estuvo detenido cincuenta días, entre diciembre de 1919 y marzo de 1920, y fue liberado tras el fallo de la Corte Suprema, el cual determinó que la justicia ordinaria no tenía jurisdicción para llevar a cabo acciones contra los impresos. Tras este dictamen, fue procesado por formar asociaciones ilícitas, a pesar de no existir investigación para determinar la existencia de dichas asociaciones ${ }^{81}$.

Un nuevo periodo de procesos judiciales, que también estuvo precedido de varios asaltos y allanamientos, se produjo a partir de marzo de 1920, en el contexto de agitación social producida por la candidatura de Arturo Alessandri ${ }^{82}$. Durante la campaña, el "León de Tarapacá" fue acusado por los conservadores de ser parte de la "ola revolucionaria, maximalista, socialista, anárquica y demagógica" "83 que estaba poniendo el jaque al país, producto de su lenguaje populista y las expresiones concretas de adhesión de los trabajadores, a pesar de que el programa de gobierno era modernizante y liberal, pero no anti-sistémico $^{84}$. Mientras se desarrollaba la campaña presidencial, el foco de atención para la policía estuvo nuevamente en los anarquistas, precisamente los mismos que habían sido recientemente liberados. El 17 de marzo se produjo un allanamiento a la Imprenta Numen, por la publicación del artículo "Jóvenes de 15 a 20" en el periódico Verba Roja, en el cual se realizaba una crítica al servicio militar, motivo suficiente para detener a los directores Armando Triviño y Manuel Antonio Silva, y ser acusados de subversión ${ }^{85}$. Días después, fue nuevamente detenido Julio Rebosio, esta vez acusado de recibir dinero desde el Perú para la publicación de Verba Roja. El proceso que se levantó contra los anarquistas esta vez fue por ultraje a la moral y las buenas costumbres y por atentar contra la seguridad interior del estado, sin embargo, la Corte de Apelaciones determinó que no eran suficientes las

\footnotetext{
80 "Sentencia No. 151: Contra Celedonio Arenas" en La Gaceta de los Tribunales. Segundo semestre 1919. Santiago, Imprenta Nacional, 1925, pp. 680.

81 "En libertad", El Surco, Iquique, 20 de febrero 1920

${ }^{82}$ Verónica Valdivia, "Yo el León de Tarapacá. Arturo Alessandri Palma. 1915-1932" en Revista Historia, Vol. 32, 1999, pp. 485-551.

${ }^{83}$ Gonzalo Vial, Historia de Chile. 1891-1973. Vol. IIII: Arturo Alessandri y los golpes militares. 1920-1925. Santiago, Ed. Santillana: 1986, p. 58.

${ }^{84}$ Valdivia (1999) Op. Cit. p. 488; Donoso (1952) Op. Cit., 243.

${ }^{85}$ M. Lagos (2012) Op. Cit., p. 23.
} 
pruebas presentadas. Tras la liberación de Triviño, Silva y Rebosio, en abril de 1920, este último tomó la decisión de suicidarse en la calle ${ }^{86}$.

A comienzos del mes de abril, experiencia similar tuvieron los militantes del POS en Antofagasta. El día 3 fue allanada la imprenta del periódico El Socialista, y detenido Luis Emilio Recabarren bajo los cargos de sedición y estafa. Esta vez no sería por una publicación escrita, sino por opiniones emitidas oralmente y por un delito económico. Además, se detuvo a Mariano Rivas, Oscar Chanks y Arturo Siempsen. Según Julio Pinto, en esta ocasión Recabarren fue acusado en Tocopilla, pero trasladado a Iquique, luego a Caleta Buena y Santiago, donde estuvo dieciséis días detenido y enviado de regreso a Tocopilla, donde finalmente se le procesó el 7 de mayo por estafa, sedición y además pertenecer a una sociedad ilícita, que sería la FOCH. Las pruebas, insuficientes como en los casos anteriores, fueron reafirmadas por funcionarios de la policía quienes aseguraron haber escuchado un discurso subversivo invocando a los bolcheviques, pero cuando él se encontraba bajo custodia policial. El proceso no avanzó y el 22 de octubre, con el pago de una fianza y sin condena, fue liberado ${ }^{87}$.

Estando el líder del socialismo en prisión (desde donde se levantó su candidatura presidencial alternativa), se produjo el conflicto fronterizo en el norte del país. Ladislao Errázuriz, ministro de guerra de entonces, trasladó al Ejército a la frontera norte frente a la posibilidad de un supuesto enfrentamiento bélico con Perú y Bolivia. Este hecho implicó una campaña nacionalista de grandes proporciones, a la cual la prensa le puso mucho esmero $^{88}$. Análisis posteriores han sostenido que este movimiento tenía por objetivo desviar la atención pública de las elecciones que había ganado estrechamente Arturo Alessandri, movilizar a la tropa del ejército alessandrista de Santiago y hacer que el Congreso eligiera presidente a su contrincante ${ }^{89}$. Pero también tenía por objetivo aplacar al movimiento obrero. El gobierno vinculó a los movimientos de izquierda con los supuestos complots de peruanos y bolivianos para recuperar los territorios perdidos tras la última guerra. Con ello, el anarquismo y el comunismo serían agentes del "oro peruano" y por lo tanto, estarían en una campaña antimilitarista y antipatriótica.

En ese contexto, se produjeron algunos hechos donde fueron protagonistas grupos de civiles, pero con amparo del aparato policial. Por ejemplo, la noche del 19 de julio se produjo un asalto a la Imprenta Numen, la que fue destruida a martillazos por una "turba de borrachos" según la versión oficial, pero la FECH sindica a este mismo grupo como los realizadores de un ataque al Club de la Federación esa noche y los agresores de los dirigentes Santiago Labarca y Juan Gandulfo ${ }^{90}$. Según Carlos Vicuña, los instigadores de ambos asaltos habrían sido "una veintena de jóvenes de buena sociedad, había entre ellos un Riesco, un Errázuriz, dos Eyzaguirre y varios otros" "1 . Dos días después, tras despedir a

\footnotetext{
${ }^{86}$ Carlos Vicuña Fuentes, La Tiranía en Chile, Santiago, s.n., 1938, p. 77; Víctor Muñoz, Cuando la patria mata. La historia del anarquista Julio Rebosio. Santiago, Ed. Usach, 2011.

${ }^{87}$ Pinto (2013), Op. Cit., 186-187.

${ }^{88}$ Gonzalo Vial, Historia de Chile (1891-1973) Vol. II: Triunfo y decadencia de la oligarquía. 1891-1920. Ed. Santillana, Santiago, 1982, p. 673.

${ }^{89}$ DeShazo, Op. Cit. 261

90 “Comienza la farsa” Juventud, Santiago, Num. 11-12, enero-febrero-marzo de 1921.

${ }^{91}$ Vicuña, Op. Cit., 95.
} 
las tropas que se embarcaban al norte en la Estación Mapocho, un desfile de civiles se dirigió desde ese lugar al Club de la FECH, para atacarlo con piedras y trozos de ladrillo, e ingresar a destruir el material del club, incendiar inmobiliario, libros y revistas ${ }^{92}$. Este hecho, provocó un enfrentamiento a balazos y la huida de los dirigentes de la FECH que se encontraban en el recinto -Juan Gandulfo entre ellos-, hacia casas vecinas. Los dirigentes resultaron finalmente detenidos y procesados por desórdenes e invasión de morada y en los días siguientes, se canceló la personalidad jurídica de la Federación.

El mismo 21 julio de 1920, el juez José Astorquiza, por orden de la Intendencia, dio curso a la detención de alrededor de doscientos asistentes a una reunión en la sede de la IWW en Valparaíso, la cual había sido allanada días anteriores para encontrar pruebas y abrir un proceso por "asociación ilícita"93. Este procedimiento fue dirigido por el prefecto de la Policía Enrique Caballero, quien habría investigado a esta organización por su intervención en la huelga portuaria que se desarrollaba por entonces ${ }^{94}$. En el allanamiento se encontraron dinamita y armas, lo que sirvió de argumentos para iniciar, en palabras de Gonzalo Vial, una "caza de brujas"95 contra conocidos militantes y simpatizantes anarquistas en Valparaíso, Santiago y otras ciudades del país.

Según el abogado Carlos Vicuña, para complementar el procedimiento, el juez pidió los procesos que aún se encontraban abiertos contra las revistas Verba Roja y Numen, a pesar de que el primer caso tenía como acusado a Julio Rebosio, quien ya había fallecido. Además se utilizaron como prueba los restos de la Imprenta Numen que habían sido recogidos por la policía después del asalto del 19 de julio. El resto de las evidencias, fueron recogidas en el allanamiento realizado a la sede de la IWW en Santiago. Según informe oficial, en esta ocasión la policía buscaba "papeles, efectos, armas o instrumentos" que tuvieran relación con la denuncia, sin embargo, sólo requisaron:

un cuadro alegórico sobre la muerte de Francisco Ferrer, un cuadro titulado $1^{\circ}$ de mayo que representa al obrero pisando el Código, el clero, el capitalismo y el militarismo; un cuadro "La Virgen Roja", y dos cuadros más sobre los periódicos "La Bandera Roja" y "La Protesta"; un paquete con proclamas de los Laboradores en Madera; dos paquetes con proclamas de la Federación de Estudiantes, varios números de los periódicos Numen, Verba Roja, Federación Obrera, El Universitario, El Ideal Obrero, Mar y Tierra, etc. etc ${ }^{96}$

Como parte fundamental del proceso se usó como evidencia las publicaciones Boletín de los Trabajadores Industriales del Mundo, Acción Directa, Verba Roja, Mar y Tierra, impresos en las Imprenta Numen de Santiago y La Batalla de Valparaíso ${ }^{97}$. Los directores (Luis A. Soza, Armando Triviño, J. Onofre Chamorro) y el dueño de la imprenta (Julio Valiente) fueron detenido y procesados. Sólo Labarca, co-propietario de Numen,

\footnotetext{
92 “Comienza la farsa” Juventud, Santiago, Num. 11-12, ene-feb-marzo 1921, p. 33-34

${ }^{93}$ DeShazo, Op. Cit., 262-263.

${ }^{94}$ Lagos (2012) Op. Cit., p. 35.

${ }^{95}$ Vial (1982), Op. Cit., p. 677.

${ }^{96}$ Lagos (2012) Op. Cit. p. 42.

97 "Un dictamen del promotor fiscal” Juventud, Santiago, Num. 11-12, ene-feb-marzo 1921, p. 111.
} 
logró huir y se mantuvo en la clandestinidad hasta noviembre de 1920. Lo interesante de este aspecto, es que el juez buscó establecer como pruebas aquellas publicaciones de circulación abierta - no clandestinas- y que ya habían salido impunes de los intentos por cerrarlas y procesarlas anteriormente. Además se sindicaba que los medios que utilizaba la IWW para obrar como asociación para "destruir el orden social" era la propaganda en toda forma "hojas volante, proclamas, folletos, periódicos, afiches, etc. Son éstos, pues, los instrumentos para la realización de su obra demoledora del orden social existente" ${ }^{\text {. }}$. La otra evidencia utilizada, fueron las armas y dinamitas encontradas en el local de la IWW en Valparaíso, elementos que permitían no aplicar la ley de imprenta sino que el Código Penal. Sin embargo, como quedó demostrado al año siguiente, tanto las armas como la dinamita requisadas en el puerto, fueron puestas en el local por agentes de la policía ${ }^{99}$, precisamente para hacer este trasvasije legal. A pesar de existir esta evidencia, la estrategia utilizada por el Promotor Fiscal, fue reinterpretar la competencia del Código Penal. Para ello, aludió a la ley de imprenta de 1846 que se encontraba expirada, la cual "contemplaba y penaba como delitos de imprenta los actos de provocar a la rebelión o sedición, a la desobediencia a las leyes o autoridades constituidas o al trastorno del orden público" y al artículo 374 del Código mencionado el cual pena "a los que vendieren, distribuyeren, o exhibieren canciones, folletos u otros escritos, impresos o no, contrarios a las buenas costumbres" por lo tanto, es de jurisdicción de los tribunales comunes los asuntos de imprenta ${ }^{100}$.

De esta manera, el promotor fiscal, apelaba a la historia de la ley de imprenta, pasando por alto las disposiciones de la legislación vigente, la cual a su parecer, era insuficiente, solicitando de manera implícita la modificación de ésta. Este proceso, que provocó conmoción pública y un debate en la prensa por el caso de los "subversivos", decayó en popularidad ante la denuncia por maltrato y torturas cometidas contra los detenidos, las que quedaron en evidencia tras la muerte del joven poeta dirigente de la FECH Domingo Gómez Rojas, víctima de las malas condiciones en que se encontraba detenido, en una celda húmeda, incomunicado gran parte del tiempo, "enloquecido" según el testimonio del abogado Carlos Vicuña ${ }^{101}$. Las repercusiones del funeral de Gómez Rojas presionaron para que los acusados por el caso "subversivos" y los dirigentes de la FECH que se encontraban detenidos, fueran liberados bajo fianza.

Si bien, el proceso no pudo llevarse a cabo, y no hubo condenas por ello, una vez más, las consecuencias para el movimiento anarquista no fueron menores. En términos humanos, a la muerte de Gómez Rojas se suma la del obrero Hipólito Vallejos en Penco, también víctima de los maltratos. Otros detenidos "salieron de la cárcel con sus facultades mentales alteradas" como Evaristo Lagos e Isidro Vidal y los obreros Luis Soza, Luis A. Troncoso y Adolfo Hernández López se contagiaron de tuberculosis. El destino común de ellos implicó que estuvieran mucho tiempo sin conseguir trabajo por haber quedado

\footnotetext{
${ }^{98}$ Ibíd., 115.

99 Se denunció públicamente que Enrique Caballero, capitán del Ejército, habría contratado a conocidos delincuentes para realizar el montaje. Para evitar proceso judicial, Caballero fue enviado por Alessandri como agregado militar a Italia y a su regreso, en diciembre de 1921, fue juzgado y absuelto de manera inmediata. Los detalles en Lagos (2012) Op. Cit., 48.

100 "Un dictamen del promotor fiscal” Juventud, Santiago, Num. 11-12, ene-feb-marzo 1921, p. 117.

${ }^{101}$ Vicuña, Op. Cit., 93.
} 
marcados por el apelativo de "subversivo"102. En términos de organización, el anarquismo también quedó desprestigiado y el uso de conceptos como "subversivo", "maximalista", entre otros, lejos de desaparecer se fue incrementando en el debate político. Según Peter De Shazo, la represión de los últimos estertores del gobierno de Sanfuentes tuvo éxito en detener la ola de huelgas que se desarrollaba y en intensificar "los odios de clase entre las elites y los trabajadores"103. En términos de su prensa, los medios involucrados en el proceso, así como otros de tendencia anarquista, sólo volvieron a publicarse entrado el año 1921, debido a la incautación de sus imprentas, consideradas medios de prueba de los delitos de asociación ilicíta y atentados contra la seguridad interior del Estado ${ }^{104}$.

\subsection{La vigilancia Alessandrista: 1921-1924}

El historial represivo del gobierno saliente dejó huellas tanto en el movimiento político-popular como en el aparato coercitivo del Estado. La nueva administración alessandrista no consiguió revertir las consecuencias del ciclo de julio de 1920, y hacia enero de 1921, aún se encontraban requisadas las imprentas anarquistas y socialistas, a pesar de haberse detenido los procesos judiciales. Tampoco pudo terminar con la práctica incorporada en la policía y en las fuerzas armadas, al momento de tratar al movimiento obrero. En ambas instituciones se acentuaban las corrientes anti-comunistas y antianarquistas, que afloraban en cada conflicto sindical. En el caso de las Fuerzas Armadas, el alzamiento que se desarrollaría en 1924 dio cuenta de la perspectiva que tenían con respecto al movimiento obrero, pues dentro del petitorio se solicitó terminar con las funciones represivas, promulgar la legislación social pero a la vez, mostraron una disposición distante y crítica del comunismo y del anarquismo, pues apostaban por la disposición a cooperar de los trabajadores, una relación armónica entre capital y trabajo ${ }^{105}$. Esta disposición de las Fuerzas Armadas ya se había explicitado durante el gobierno de Alessandri, a través de informes enviados al Ministerio del Interior donde se denunciaba que la legislación de imprenta es "demasiado liberal" para contener la publicación de "artículos subversivos, desquiciadores del orden público, atentatorios contra la seguridad interior del estado" los cuales son muy difundidos entre los trabajadores. Finaliza uno de los informes señalando que "la ley, en realidad, favorece estos desmanes por cuanto la pena que establece es insignificante comparada con la gravedad del hecho i la dificultad del procedimiento judicial",106

En el caso de la policía el panorama sería más o menos similar. Según lo concluido por Jorge Rojas y Gonzalo Rojas, este cuerpo tenía un acercamiento con los trabajadores pues reconocían la legitimidad de las demandas, pero mostraban un distanciamiento con los dirigentes "al considerarlos elementos ajenos al movimiento obrero y dañinos a sus propios

\footnotetext{
${ }^{102}$ Lagos (2012) Op. Cit., pp. 48-49.

${ }^{103}$ DeShazo, Op. Cit., 264.

104 "Nuestro Silencio", El Surco, Iquique, 28 de marzo 1921. P. 1

${ }^{105}$ Vial (1986) Op. Cit. p. 386. Augusto Varas, Felipe Agüero, Fernando Bustamante, Chile, democracia y Fuerzas Armadas. Santiago, Flacso, 1980, capítulo 4.

${ }^{106}$ Archivo Nacional de la Administración, Fondo Ministerio de Guerra, “Auditor de Guerra a Ministro del Interior", Vol. 4520, 7 de enero 1922.
} 
intereses"107. Ambas entidades identificaron a los dirigentes considerados "agitadores" lo que permitió que durante el gobierno alessandrista, la represión estuvo más focalizada hacia ellos, a través del mismo mecanismo de control y documentación de las reuniones y movimientos de sindicatos. Al comenzar la nueva administración, se sucedieron dos huelgas que tuvieron como resultado la muerte de decenas de trabajadores. En febrero se movilizaron los obreros pampinos en la oficina San Gregorio, realizando una protesta contra la cesantía y la paralización de las faenas salitreras y en el mes de abril, fue el turno de los mineros del carbón en Curanilahue ${ }^{108}$. En ambos casos las manifestaciones fueron controladas por personal del Ejército, mostrando los límites de la política de Alessandri, a pesar de tener un discurso conciliador hacia los trabajadores, mostraba tempranamente su distancia de las líneas comunistas y anarquistas ${ }^{109}$.

Sobre la represión a la prensa obrera, los episodios son menos frecuentes que el bienio anterior, pero se mantuvieron los mecanismos ya descritos. Por ejemplo, el 23 de noviembre de 1921, se produjo un ataque incendiario a la imprenta de La Federación Obrera, ubicada en el mismo local de la sede sindical. Según su versión, a las 2.45 de la mañana se sintió una explosión y un automóvil huyendo, y se inició un incendio que los obreros que estaban en el local lograron aplacar rápidamente. La editorial atribuyó el atentado a su campaña de denuncia de los fraudes cometidos con los albergues, medida que mantuvieron, pues consideraba que los ataques buscaban silenciarlos. ${ }^{110}$ En esta ocasión, la acción fue llevada a cabo por civiles, de los cuales no se conoció su identidad, y a pesar de la denuncia interpuesta por la $\mathrm{FOCH}$, no hubo investigación ni conclusiones al respecto. Sin embargo, tres días después, el local sería registrado por la policía, en el contexto del velatorio del obrero Luis Reveco ${ }^{111}$, quien resultara muerto en el enfrentamiento producido entre los obreros y la policía en el marco de una movilización para apoyar una huelga en un fundo perteneciente a Eliodoro Yañez, situado en San Bernardo ${ }^{112}$. Esa intervención en la sede, vista como una ofensa por la $\mathrm{FOCH}$, implicó "un prolijo registro de todas las dependencias de la imprenta, sin escapárseles siquiera los cajones de los escritores de la administración y redacción del diario" "113. La intencionalidad de la policía y del juez Soto Barriga, quedó transparentada, cuando la tarde del 7 de diciembre se realizó un nuevo allanamiento, esta vez, por la sospecha de que en esos talleres se había impreso la proclama "Al Soldado", la cual fue reproducida por el periódico La Federación Obrera el día 2 de diciembre. Según la denuncia, la proclama impresa como hoja suelta, estaba siendo repartida afuera de los regimientos y hacía un llamado a la rebelión de los cadetes ${ }^{114}$.

\footnotetext{
${ }^{107}$ Rojas y Rojas, Op. Cit., 301.

${ }^{108}$ Grez, Op. Cit. p. 135.

${ }^{109}$ DeShazo, Op. Cit. 268.

110 "Incendio en nuestra imprenta. La mala fortuna de nuestros enemigos" La Federación Obrera de Chile, Santiago, 24 de noviembre 1921, p. 1.

${ }^{111}$ Rojas, Op. Cit. 65-66.

112 Pinto, Op. Cit., 218.

113 "Nuevos atropellos a la imprenta de los trabajadores, de parte de las autoridades". La Federación Obrera de Chile, Santiago, 8 de diciembre 1921, p. 1.

114 "Esa masa heterogénea de hambrientos y andrajosos que se unen en las calles para pedirle a los potentados un mendrugo de pan y un trato más humano y que, por sus sagradas exigencias llegan a incomodar al
} 
A pesar del allanamiento y del proceso judicial, la redacción del diario decidió publicar nuevamente la proclama aludida, amparándose en la Constitución y la ley de imprenta, pues lejos de considerarla ilegal, señalaban que "contiene una exposición de ideas completamente lógicas" y por lo tanto, pueden hacer "(...) uso de un derecho público, consagrado en los Códigos cual es el de emitir nuestros pensamientos que nacen al calor de una ambición de mayores libertades en favor de los que sufren opresión y son obligados por la fuerza organizada de la clase dominante, a hacer la voluntad ajena" ${ }^{\text {"15 }}$. En su defensa, señalaban que no eran los autores originales del texto, que éste era conocido y que un juzgado local no puede procesar por delitos de imprenta, pues ya lo había señalado la Corte Suprema para los casos de Verba Roja y El Surco en años anteriores ${ }^{116}$. El director del periódico, Manuel Hidalgo, señaló que de existir algún abuso debían ser un jurado de imprenta el que debiera deliberar y que tampoco procede procesar por el Código Penal pues no puede haber delito de rebelión o sedición si ésta no se ha producido"117. De esta manera, Hidalgo se amparaba en el principio de la libertad de expresión protegido por la Constitución, dando cuenta de los límites con que actuaba el juez y el promotor fiscal y rememorando el montaje realizado por la policía contra la IWW en 1920.

Este caso marcó un precedente para el gobierno alessandrista, el cual no desarrolló una política ampliada de censura de la prensa obrera, pero sí estableció un límite a la libertad de expresión, dado por la alusión a las Fuerzas Armadas. Esto queda demostrado en que el siguiente proceso que se intentó abrir fue contra el dirigente comunista Salvador Barra Woll, en mayo de 1922, por publicar en El Despertar de los Trabajadores un artículo titulado "Obrero soldado" en el cual interpelaba a los jóvenes militares, dando cuenta de su condición de clase obrera $^{118}$. El informe de la policía para justificar la detención, señala que el artículo constituye "una instigación a la desobediencia y a la rebelión que se hace a la fuerza armada" y proclama que el autor "además de ser responsable de abuso a la libertad de imprenta merece la sanción que por estos delitos determina la ley" ${ }^{119}$. De esta manera, la policía nuevamente intentó apelar al delito contemplado en el Código Penal de instigar la rebelión y como prueba no sólo se usó la proclama sino también el hecho que Barra "lanzaba injurias contra varias personas en la calle Baquedano"120.

Según el diputado Víctor Cruz, Salvador Barra había sido citado anteriormente a la oficina del Intendente en Iquique, donde se le exigió que terminaran las manifestaciones de

poderoso que, sin conmoverle los lloros de las santas madres y de los tiernos angelitos jinocentes flores de este mundo morboso! Te mandan a ti para que los ametralles o disperses a sablazos cuando menos sin que tú te des cuenta que lo haces con tus padres y tus hermanos. (...) ¡Rebélate contra ese régimen odioso que te oprime! ¡Haced, hermano soldado, lo que hicieron tus hermanos de la Gloriosa Rusia, que hoy es el faro esplendoroso y la cuna del derecho y la justicia". En "Nuevos atropellos a la imprenta de los trabajadores, de parte de las autoridades”. La Federación Obrera de Chile, Santiago, 8 de diciembre 1921, p. 1.

115 “Golpe de Autoridad” La Federación Obrera de Chile, Santiago, 9 de diciembre 1921, p. 1

116 "Al margen del allanamiento de la imprenta" La Federación Obrera de Chile, Santiago, 10 de diciembre 1921 , p. 1.

117 "La Proclama subversiva” La Federación Obrera de Chile, Santiago, 13 de diciembre 1921, p. 1

118 “Al obrero soldado", El Despertar de los Trabajadores, Iquique, 1 de mayo 1922. La proclama volvió a ser publicada por el mismo periódico y por Justicia, Santiago, el 8 de mayo de 1922.

119 Archivo Regional de Tarapacá, Fondo Intendencia de Tarapacá, Vol. 1261, Notas de Policía 1922

120 Ídem. 
los obreros cesantes en demanda de mejores condiciones de trabajo en las oficinas salitreras $^{121}$, y por lo tanto, el incidente del artículo habría sido una excusa para detenerlo. Por otro lado, el abogado defensor señaló que no existía el delito de instigación a la sublevación a las Fuerzas Armadas, toda vez que ella no se había producido y en esta proclama (a diferencia de la anterior) no había un llamado explícito a la rebelión, sino a que los soldados reflexionaran ${ }^{122}$. A pesar de lo anterior, el dirigente estuvo cuarenta y siete días preso, periodo en el cual se realizaron mitines en Iquique y Santiago por su liberación $^{123}$, volviendo a la palestra el tema de la libertad de expresión. En el mismo mes, se denunció que en las oficinas salitreras, por orden de "Carabineros de Santiago" estaba prohibido realizar reuniones dentro y fuera de las oficinas, y la circulación de la prensa comunista $^{124}$. Frente a los hechos, Recabarren se manifestó en el Congreso señalando que la prensa comunista y aristocrática tenían el mismo derecho a circular, y sobre la detención de Barra Woll, volvió sobre el aspecto legal:

En Chile hay una ley de imprenta a la cual se remite todo lo que se considere un acto que signifique un abuso de la libertad de imprenta. Los tribunales de justicia, que los Honorables Diputados siempre se empeñan en demostrar que cumplen con sus deberes y que se empeñan en desprestigiar diariamente las funciones confiadas a su cargo, han ordenado reducir a prisión a este ciudadano, sólo por haber firmado un artículo (...) Y yo me pregunto honorables diputados ¿de qué sirve que la Corte Suprema haya dicho que no se puede procesar a ningún ciudadano porque haya escrito un artículo cuando los jueces no quieren atenerse a ese proceder y ordenan llevar a la Cárcel a un ciudadano por que ha escrito un artículo? ${ }^{125}$

Tras la liberación de Salvador Barra ${ }^{126}$, se produjo un atentado incendiario a la imprenta del periódico, según la versión del mismo dirigente, realizada por un antiguo líder de las Ligas Patrióticas, Jorge Pavelich, quien actuaba bajo el amparo de la policía de Iquique $^{127}$. Este hecho fue confirmado por el diputado comunista Víctor Cruz, quien aseguró que los ejecutores del atentado fueron personal de la policía, los que ya habían amenazado a los redactores del periódico ${ }^{128}$. Este incendio destruyó las instalaciones del

${ }^{121}$ Sesión $38^{\text {a }}$ ordinaria, 15 de julio 1922, en Cámara de Diputados, Boletín de Sesiones Ordinarias 1922, Imprenta Nacional, p. 1029.

122 "Comentarios a la valiente y hermosa defensa que presentó el abogado, ciudadano Nicolás Vallejos Encina" El Despertar de los Trabajadores, Iquique, 20 de mayo 1922.

123 "Los procesos-farsas a los subversivos. Barra Woll sale en libertad", El Despertar de los Trabajadores, Iquique, 24 junio 1922; Julio Pinto, Verónica Valdivia, ¿Revolución proletaria o querida chusma? Socialismo y alessandrismo en la pugna por la politización pampina. 1911-1932. Santiago, Ed. Lom, 2001, p. 82-83.

${ }^{124}$ Sesión $25^{a}$ Extraordinaria, 19 de mayo 1922, en Cámara de Diputados, Boletín de Sesiones Extraordinarias 1921-1922, Imprenta Cervantes, 1922, p. 695.

${ }^{125}$ Ídem.

${ }^{126}$ El fallo por este caso, según Sergio Grez, resultó favorable para el dirigente pues la Corte dictaminó que no había pruebas suficientes para dictar sentencia condenatoria. Grez, Op. Cit. p. 203.

127 "El incendio de ayer. Los grandes atentados criminales", El Despertar de los Trabajadores, Iquique, 2 de julio 1922; Pinto y Valdivia, Op. Cit., 83.

${ }^{128}$ Intervención de Víctor Cruz en Sesión $38^{\text {a }}$ ordinaria, 15 de julio 1922, en Cámara de Diputados, Boletín de Sesiones Ordinarias 1922, Imprenta Nacional, 1923, p. 1027. 
teatro y la universidad popular que funcionaba en el local, pero no afectó a los talleres de la imprenta.

El acoso contra la prensa comunista en la pampa tuvo un nuevo episodio en diciembre de 1922, se denunció que en las oficinas salitreras se impedía la circulación y venta de El Despertar de los Trabajadores y en general de todo impreso relativo a la FOCH y que ello había tenido como consecuencia la detención de un obrero por portar ese periódico $^{129}$. Este incidente sucedió en el contexto en que toda actividad obrera era boicoteada, así como los viajes de los dirigentes a la pampa y prohibiendo y disolviendo las reuniones, mitines y manifestaciones.

Al año siguiente, en el marco de la huelga portuaria producida en contra de la abolición del sistema de redondilla, en Iquique, Pisagua, Junín, Caleta Buena y Tocopilla, los anarquistas fueron el objetivo. Durante los primeros días de octubre de 1923, como medio de contener la huelga, la policía realizó un allanamiento a la sede del Sindicato de Jornaleros y Estibadores, con el pretexto de buscar bombas y dinamitas. En ese procedimiento, fue destruida la imprenta del Centro de Estudios La Brecha que funcionaba en aquel recinto, y secuestrados los "carteles, manifiestos e impresos". El diputado comunista Víctor Cruz denunció en la Cámara que había sido el prefecto de la policía de Iquique, de apellido Souper "por su propia mano y ayudado por personal de su mando" quien comandó la destrucción de la imprenta ${ }^{130}$. Días después, fueron detenidos por la policía tres obreros por "repartir manifiestos en la calle" y se constató que estos fueron azotados por agentes. La defensa del Ministerio del Interior sostuvo que el allanamiento se produjo por orden judicial, solicitada por la Sección de Pesquisa a través del Intendente, porque tenían información que en la sede se encontraban explosivos, por lo tanto, no habría habido irregularidad en el procedimiento. Sin embargo, los detenidos fueron liberados inmediatamente porque no habían pruebas para formalizarlos.

Días después de este hecho, se produjo, de manera inédita, un juicio de imprenta contra El Despertar de los Trabajadores, tras la acusación de que se había injuriado a la justicia y buscaba alterar el orden social "para implantar el comunismo que es caos, desorden y miseria"131. Este proceso, se debía ejecutar a través de dos jurados, el primero que determinaría si había lugar a la causa y el segundo que juzgaba y aplicaba la sentencia. Este último, debía estar compuesto por personas propuestas por ambas partes, acusado y acusador, sin embargo el fiscal pretendió invalidar a los jurados comunistas, porque éstos no "juraban por dios". La otra denuncia señalaba que el Fiscal confundía el comunismo con el anarquismo y pretendía insultar con los conceptos "subversivos" y "criminales" a quienes buscaban un "cambio social"132. Como apreciamos, en este único caso que hemos encontrado de aplicación del procedimiento de la ley de imprenta, construido por "injurias" contra funcionarios públicos, de todas maneras se utilizaron los argumentos políticos para

\footnotetext{
${ }^{129}$ Pinto y Valdivia, Op. Cit., 87.

130 Sesión $2^{\text {a }}$ Extraordinaria, 17 de octubre 1923, en Cámara de Diputados, Boletín de Sesiones Extraordinarias 1923-1924, Imprenta Nacional, 1924, p. 31 y 34.

131 "En la acusación a "El Despertar" el jurado lo declara absuelto". El Despertar de los Trabajadores, Iquique, 30 de octubre 1923.

132 "La defensa de Barra Woll en la acusación a "El Despertar”, El Despertar de los Trabajadores, Iquique, 31 de octubre 1923.
} 
buscar responsabilidad penal de la prensa obrera. En este sentido, Salvador Barra Woll, director del periódico, defendió la labor que realizaban, pues no se trataba de subversión sino de "denunciar la verdad ante todo", señalando que su labor era difundir el "apostolado revolucionarios para combatir la maldad social y abogar por la justicia de los principios sociales del proletariado" "133. Tras los alegatos de ambas partes, el jurado resolvió absolver a El Despertar y consideró que la acusación no tenía pruebas, quedando el periódico impune nuevamente. Este hecho no detuvo las críticas al medio impreso ni los intentos de destruir su imprenta. A comienzos de 1924 se denunció a través de sus páginas un intento de incendio, ocurrido a media noche del 25 de enero. El informe de la Intendencia detalló que las puertas y ventanas fueron empapadas con parafina y "luego se le prendió fuego y que días antes se habían encontrado cartuchos de dinamitas en el techo del taller"134. El incendio se contuvo por la acción de los habitantes del lugar, vecinos y de un guardián, quienes reaccionaron rápidamente, lo que evitó un desastre mayor.

Como hemos visto, hasta antes de la intervención militar de septiembre de 1924, la represión contra la prensa continuaba siendo una herramienta aplicada como parte de los múltiples mecanismos de represión al movimiento obrero, por lo tanto, los episodios más emblemáticos de censura de prensa tienen directa relación con la intensificación de algún conflicto, huelga o movilización. Además, bajo el gobierno alessandrista, se sumó la sensibilidad al discurso antimilitarista, el cual fue atacado en dos ocasiones. Pero este periodo también implicó el empoderamiento, sobre todo de la prensa comunista, de los derechos ciudadanos, frente a los intentos por penalizar el pensamiento político. Eso se evidencia no sólo en la defensa de estos medios sino también en los argumentos que se esgrimieron para exigir la libertad de reunión y de asociación. La defensa de la libertad de expresión, desde el movimiento obrero, continuó estando dentro de los parámetros de las libertades individuales, consagradas por la Constitución de 1833, entre las que se incluyen la libertad de reunión y de asociación.

Los comunistas denunciaron en varias ocasiones que la ley era violada en el país por la intendencia, los jueces y la policía, los que actuaban a favor de los empresarios y de los dueños de las oficinas salitreras, quienes prohibían las reuniones y la circulación de la prensa obrera, sin considerar los derechos fundamentales consagrados por la Constitución. Al no existir una legislación específica que prohibiera o penalizara la opinión política, la aplicación de la ley era arbitraria y desigual, pues el sistema legal amparaba el argumento comunista. Sólo tras el golpe militar de 1924, la censura de prensa sería una preocupación específica y permanente para el gobierno y se aplicaría de manera transversal a todo el espectro político.

\footnotetext{
133 Ídem.

134 “Telegrama N No $^{\mathrm{8}}$ 82, de Iquique a Interior, 26 de enero de 1924”. Ministerio del Interior, Vol. 6130, Providencias.
} 


\section{LA INTERVENCIÓN MILITAR Y EL CONTROL DE LA PRENSA POR DECRETO.}

El movimiento militar que irrumpió la actividad político-institucional del país en septiembre de 1924, tuvo como implicancias la aprobación de la legislación social y la modificación de la estructura administrativa del Estado. Según Gonzalo Vial, el petitorio de los militares al Ejecutivo implicaba solicitudes gremiales relativas a las FFAA como las leyes de retiro y ascenso, hasta medidas políticas como la promulgación de un Código del Trabajo, pago de sueldos pendientes a empleados fiscales, estabilización de la moneda, entre otros ${ }^{135}$. Pero también, se motivaba en una crítica a los partidos políticos, pues consideraban que éstos se movilizaban sólo por intereses particulares, descuidando el bienestar y futuro de la nación. Dentro de su concepción política, las distintas clases debían funcionar en cooperación tras el interés nacional y no en conflicto ${ }^{136}$. Debido a la crítica al sistema político y los anhelos por "recuperar" el bienestar nacional, los militares en el poder buscaron la simpatía de los distintos sectores sociales, incluido el movimiento obrero, para lo cual asistieron a las sedes de sindicatos y lugares de reuniones de las sociedades e informaron la obra de la Junta Militar y las proyecciones futuras e hicieron un llamado a la colaboración ${ }^{137}$. La reacción del movimiento obrero y sus corrientes políticas, vaciló entre el rechazo absoluto al nuevo régimen, y la aprobación y expectativas positivas debido a la vocación laboralista de los militares. Con el correr de los días, la nueva junta iría mostrando el carácter de su gobierno, y develando su parecer con respecto a las demandas obreras y su distanciamiento del comunismo y del anarquismo ${ }^{138}$. Así, la postura que tendría el nuevo gobierno frente a la prensa obrera sería de máxima cautela y supervisión de los contenidos emitidos por estos medios.

Según el testimonio de Carlos Vicuña, a las 4 de la mañana del día 27 de septiembre, varias comisiones de militares recorrieron los periódicos para realizar una supervisión de las pruebas de imprenta y aprobar o rechazar los artículos que se incluirían en la edición. También, habrían llevado varios artículos para ser incorporados en el periódico, todos "de violenta amenaza contra los perturbadores del orden"139. De esta manera, se habría instalado por primera vez en la historia del país la censura previa a la prensa, ejecutada por funcionarios militares en los lugares de la imprenta, a lo que se sumó la obligación de publicar noticias redactadas por el gobierno ${ }^{140}$. A medida que avanzaron los meses, este procedimiento inédito se mantuvo en algunos medios, y tras el nuevo golpe militar de enero de 1925, se agudizaron las disposiciones de control a pesar de ser inconstitucional.

\footnotetext{
${ }^{135}$ Vial (1986) Op. Cit., p. 386.

${ }^{136}$ Varas, Agüero y Bustamante, Op. Cit.

137 "La visita de una comisión de la Junta Militar a la Unión Local de la IWW" en Tribuna Libertaria, No. 18, $2^{a}$ quincena de septiembre 1924.

138 De Shazo, Op. Cit. 308.

${ }^{139}$ Vicuña, Op. Cit., 192.

140 Ídem.
} 
Otra medida aplicada en octubre de 1924 consistió en la clausura de la imprenta del periódico La Defensa Obrera de Tocopilla ${ }^{141}$. Este hecho fue visto por la prensa comunista como un ataque a la libertad de expresión, "la más cara de las libertades públicas y consagrada universalmente" ${ }^{142}$. Según el gobernador del departamento, la clausura se produjo luego que se detuviera al director de este medio, Juan Luis Carmona Avilés mientras intentaba dar "conferencias subversivas" en la oficina salitrera Coya. En ese lugar, fue aprehendido por personal de Carabineros (como se denominaba la policía rural en ese entonces), y conducido a la oficina del Gobernador, donde según la versión de la autoridad del departamento, Carmona "lo injurió groseramente y pretendió agredirlo con su revólver, lo que no consiguió por haber intervenido oportunamente, tropa de esta repartición" "143. El director del periódico negó el hecho y publicó un artículo donde acusó al "Capitán Cristi" de haberle imputado "el hecho falso de haber pretendido agredir al vice-primero destacado en esa oficina en el propio cuartel, siendo que lo ocurrido fue que el vice-primero hizo llamar a Carmona al cuartel donde lo allanó y detuvo su revólver" ${ }^{144}$ a pesar de que tenía permiso para cargar armas. Esta publicación fue considerada injuriosa por la Intendencia, la que decidió clausurar el periódico a pesar de no tener atribuciones legales para hacerlo.

Este hecho, más la expulsión del abogado Daniel Schweitzer, confirmaron las sospechas de los anarquistas y parte de los comunistas que esperaban el golpe de poder de las FFAA. Frente a ello, la crearon el "Comité Pro Libertades Públicas" cuya finalidad era "agrupar a todas las instituciones obreras, estudiantiles y centros de estudios sociales con el objeto de tener un sólo frente que trabaje por los asuntos que interesan a los productores en general" y trabajar por "la pronta restauración de las libertades públicas" configurándose una oposición visible al gobierno militar ${ }^{145}$. Este movimiento, que aspiraba a ser transversal, realizó un llamado a paro general por las libertades públicas a fines de octubre $^{146}$ y solicitó entre sus puntos principales, la reapertura del periódico recién clausurado $^{147}$. Finalmente, se decretó la libertad de Carmona y la reapertura de La Defensa Obrera el 31 de octubre ${ }^{148}$.

La ofensiva contra la prensa se retomaría a raíz del golpe de estado de 1925, cuando la nueva junta militar esperaba restaurar los principios del movimiento del año anterior. En ese entonces, se produjo el insólito cierre del periódico El Diario Ilustrado, de tendencia conservadora pero muy crítica de los militares. Su edificio fue tomado por efectivos del

\footnotetext{
141 “La Defensa Obrera” de Tocopilla", Justicia, Santiago, 22 de octubre 1924, p. 1

142 "La clausura de la imprenta obrera de Tocopilla" Justicia, Santiago, 23 de octubre 1924, p. 1

143 "Gobernador de Tocopilla al Intendente de Antofagasta", 16 de octubre de 1924, Ministerio del Interior, V. 6141, Providencias, 8-26 nov de 1924.

144 "La Defensa Obrera" de Tocopilla es clausurada por orden de la autoridad", El Despertar de los Trabajadores, Iquique, 22 de octubre de 1924.

145 “Comité pro-libertades públicas", Justicia, Santiago, 25 de octubre 1924, p. 3

146 "La Junta Ejecutiva de la Federación Obrera hace llamado a la clase trabajadora nacional para que se prepare a defender el mínimun de libertades públicas de que hasta hoy había gozado”, Justicia, Santiago, 29 de octubre 1924, p. 1

147 “La Federación Obrera de Chile se dirige al Comité Militar” La Nación, Santiago, 31 de octubre 1924, p. 8

148 “Se levanta la clausura de la imprenta de Tocopilla” Justicia, Santiago, 1 de noviembre 1924
} 
Ejército bajo el pretexto de ser un lugar estratégico para la defensa de La Moneda por estar ubicado justo en la calle de al frente ${ }^{149}$. Dicha medida fue criticada, incluso, por medios adversos a este periódico, como La Nación desde donde se señaló que a pesar de la responsabilidad de El Diario Ilustrado en la crisis política del país, debe ser el juicio público el que lo sancione y no la autoridad administrativa, defendiendo la libertad de expresión sin restricciones ${ }^{150}$.

Este sería sólo el primer paso, pues la nueva junta emitiría un mandato a los periódicos para evitar las publicaciones "perturbadoras de la tranquilidad pública, las actitudes contenciosas e intransigentes, las afirmaciones dirigidas a fomentar la desconfianza y las divisiones entre las fuerzas nacionales" ${ }^{\prime 151}$. Por no acatar esta orden, fue clausurado nuevamente el periódico El Diario Ilustrado junto a La Unión de Valparaíso, acusados de publicar noticias encaminadas a socavar el orden existente ${ }^{152}$. Este hecho abrió una encendida polémica con respecto a la libertad de expresión ${ }^{153}$, que resolvieron los militares con un nuevo marco legal.

La primera iniciativa se promulgó el 4 de marzo ${ }^{154}$, y modificaba algunos artículos de la legislación decimonónica, aumentando la pena a los dueños de imprentas que no indicaran al final de cada impreso los datos de su taller, fecha de publicación y lugar de edición; así como a quienes no cumplieran con el envío de ejemplares de los impresos a la Biblioteca Nacional, al acusador público y gobernador departamental correspondiente, siendo estas tres entidades las encargadas de aplicar las multas. De todas maneras, esta normativa no tuvo funcionamiento real, pues se anunciaba que operaría a partir del 1 de abril, y el 26 de marzo el Ministro de Justicia José Maza, despachó otro Decreto Ley, con el número 425 y denominado "Sobre Abusos de Publicidad". Esta normativa, que implicó la derogación de la ley de 1872, mantenía como principio fundamental el hecho que en Chile no existiría censura previa y que sólo se castigarían los "abusos de este derecho" punto importante es que esta normativa ya no abarcaría sólo los impresos, sino "la transmisión pública i por cualquier medio de la palabra, oral o escrita", considerando entonces los nuevos medios de transmisión de mensaje que existen en la época como la radiotelefonía, el cinematógrafo, telégrafo y los que surgirán en el futuro, abarcando también los discursos públicos y privados.

Es importante considerar que el Decreto Ley 425 creó un sistema de registro y control de los viejos y nuevos medios escritos, a través del envío de copias de todos los ejemplares impresos a la Biblioteca Nacional, Biblioteca del Congreso Nacional y al gobierno departamental. Para el caso específico de la prensa, revista o escrito periódico, el director del medio debería inscribirlo ante el Gobernador departamental, el que elaboraría

\footnotetext{
${ }^{149}$ Vicuña, Op. Cit., 245.

150 “Clausura de "El Diario Ilustrado” La Nación, Santiago, 24 de enero 1925, p. 5.

151 "Los derechos y los deberes de la prensa”. La Nación, Santiago, 15 de febrero 1925, p. 11.

152 "La censura periodística” La Nación, Santiago, 18 de febrero 1925, p. 3.

153 "El Gobierno y la libertad de prensa" La Nación, Santiago, 18 de febrero 1925, p. 3

${ }^{154}$ Nos referimos al Decreto Ley No. 281

${ }^{155}$ Ministerio de Justicia, Decreto Ley 425, Sobre abusos de la publicidad, 26 de marzo 1925. Disponible en http://bcn.cl/1mtob, (consultada el 16 de junio 2014).
} 
un registro ${ }^{156}$. A su vez, todo impreso debía llevar indicado el nombre de la imprenta, lugar y fecha en que fue editado. La desobediencia a las indicaciones mencionadas sería considerada una falta, sancionada con multa que iba desde los 200 a los 500 pesos, y el Gobernador, el Promotor Fiscal y el Director General de la Biblioteca serían los encargados de hacerlas cumplir. Por otro lado, este decreto eliminó el concepto de "abuso" y determinó "delitos", asignándole a los tribunales ordinarios competencia para estos casos, los cuales debían actuar según las normas establecidas en el Código de Procedimiento Penal. En esta disposición, se estableció que serían castigados como cómplices los que por medio de la transmisión de un mensaje (en cualquiera de sus medios, públicos y privados) hubieran incitado directamente al autor o autores de un crimen o un delito, aunque éste se haya frustrado. Otros contenidos penalizados fueron los que indujeran a las FFAA "a infringir sus deberes militares o a desobedecer a sus superiores jerárquicos", los que se basaran en noticias falsas "documentos supuestos o adulterados", los "gritos o cantos sediciosos en lugares o reuniones públicas", y también los "ultrajes a las buenas costumbres"157.

Como se puede apreciar, esta tipificación reúne aquellos delitos que anteriormente no habían podido ser penalizados con la legislación anterior, y por los cuales se intentó frustradamente procesar a la prensa obrera. De esta manera, se le entregó las herramientas al gobierno para sancionar la disidencia política por la vía legal, pero manteniendo como principio fundamental la libertad de expresión. Con ello, se conservaba el espíritu liberal de la Constitución Política de 1833 y que fue reafirmada en la carta promulgada en septiembre de 1925. El argumento para legitimar el DL 425 fue el resguardo de la seguridad de la nación por sobre los derechos y libertades individuales, tras lo cual también se buscó controlar la información sobre delitos y crímenes o incluso de procesos judiciales, cuya publicación quedaba bajo la autorización de los tribunales a cargo.

La publicación de este decreto provocó variadas críticas desde la prensa anarquista y comunista. En El Despertar de los Trabajadores se señaló que "es una vergüenza (...) que se instituya una ley que viene a despojar a los habitantes de esta faja de tierra de esas facultades legadas a costa de la vida de los redentores de otrora" y que "no se acalla a un pueblo con castigos. Los gritos de la muchedumbre no se extirpan con mordazas, porque más que sangren sus encías, ellos gritarán" "158. A pesar de la existencia de este marco legal, en los meses siguientes la actitud del gobierno frente a la prensa obrera mantuvo la dinámica de los años anteriores. En el mes de junio se produjo el desenlace de una ola de huelgas en la pampa salitrera producida tras la demanda de aumento de salario, la jornada laboral de ocho horas, el reconocimiento de la Federación Obrera de Chile como interlocutor y la demanda por protección de las libertades públicas, siendo fundamental la

\footnotetext{
${ }^{156}$ En el caso de la Intendencia de Santiago, este registro quedó archivado en el volumen 584, el cual reúne cientos de declaraciones de directores de periódicos entre el 31 de marzo de 1925 y 30 de diciembre de 1928. Cada registro contenía el nombre del medio, director responsable, imprenta, nombre de los dueños del medio y/o de la imprenta, periodicidad de la publicación y dirección. También hay declaraciones que informan cambio de director, de dueño y de imprenta.

${ }^{157}$ Ministerio de Justicia, Decreto Ley 425, Sobre abusos de la publicidad, 26 de marzo 1925. Disponible en http://bcn.cl/1mtob, (Consultada el 16 de junio 2014).

158 "Se pretende encadenar la Libertad de Imprenta", El Despertar de los Trabajadores, Iquique, 10 de abril 1925.
} 
libre circulación de la prensa obrera en las oficinas salitreras ${ }^{159}$. En ese contexto, el día 2 de junio fueron clausuradas las imprentas de El Despertar de los Trabajadores en Iquique y de El Comunista en Antofagasta. Según información oficial, el motivo de la clausura era que estos medios realizaban "constante incitación a la huelga y a la subversión" y "en sus columnas se insultaba a las autoridades constituidas en dignidad y se aconsejaba a los obreros a faltar el respeto"160. Sólo días después, en la oficina salitrera La Coruña, se produjo un enfrentamiento entre los obreros y las Fuerzas Armadas, que terminó en una nueva masacre, detenciones y juicios a los dirigentes de la FOCh y del Partido Comunista. Así como para contener las huelgas se mantuvo la aplicación de la ley marcial, en el caso de la prensa, a pesar de existir una legislación que establecía un procedimiento para sancionar los delitos que se le acusaban, la Intendencia optó por el allanamiento e incautación de la imprenta sin conducir a proceso. Incluso, el periódico acogiéndose a la Ley de Amnistía de septiembre de 1925 solicitó la devolución de las maquinarias, a lo cual la Intendencia respondió negativamente ${ }^{161}$.

A pesar de este episodio, tanto El Despertar de los Trabajadores como otros medios políticos populares continuaron publicándose, en condiciones cada vez más paupérrimas por la falta de financiamiento, pero también por los controles impuestos por el gobierno, ahora cívico-militar. En las páginas de Tribuna Libertaria se explicitó con una página en blanco que el artículo "Las garras y los tiranos" no había sido publicado porque no fue autorizado $^{162}$. Así mismo, el informe enviado a la Komintern en octubre de 1925 señala que "la situación del partido [Comunista] es casi ilegal. La censura militar no permite hablar de estos hechos con la oportunidad debida en los diarios comunistas"163.

A pesar de esta información, que se pudo filtrar en la misma prensa obrera, no es posible establecer en detalle de qué manera funcionó la "censura militar". Sólo podemos detectar que el camino continuado no fue la aplicación del decreto ley promulgado, sino que se perpetuó la práctica represiva de los allanamientos, incautaciones y clausuras, sumándose ahora el control previo de las publicaciones. Tampoco tenemos certeza de si esa censura previa fue aplicada a todos los medios o sólo a los considerados más sospechosos por el gobierno. La no existencia de una entidad que se dedicara a ello, nos impide detectar de manera clara su funcionamiento, y sólo podemos especular a partir de los resultados. Por ejemplo, la tesis del abogado Enrique Didier, publicada en 1933, señala que en ese entonces aún no existía jurisprudencia de "Abusos de Publicidad", y sólo se habían producido dos casos hacia $1930^{164}$. Tampoco tuvo efecto el Decreto Ley No. 670 promulgado en

159 Rolando Alvarez, "La matanza de La Coruña. Chile, 1925”, disponible en http://www.luisemiliorecabarren.cl/files/recursos/Matanza_en_La_Coruna.pdf, p. 29-34. (consultada el 20 de marzo 2015).

${ }^{160}$ Archivo Regional de Tarapacá, Fondo Intendencia de Tarapacá, Vol. 1328 Confidenciales 1924-1925

161 "Por qué no se nos entrega nuestra imprenta" El Despertar de los Trabajadores, Iquique, 19 de noviembre 1925.

162 Tribuna Libertaria, No. 20, $2^{\mathrm{a}}$ quincena de marzo 1925 , p. 3.

163 Olga Ulianova y Alfredo Riquelme, Chile en los archivos soviéticos: 1922-1991. Tomo II. Komintern y Chile. 1931-1935. Santiago, Centro de Investigaciones Diego Barros Arana, Lom Ediciones, 2009, p. 145.

${ }^{164}$ Didier, Op. Cit. 
noviembre de 1925 en que se establecía la censura de la publicidad y correspondencia privada en tiempos de guerra, pues fue derogado al año siguiente.

En suma, en el periodo que hemos estudiado, los gobiernos de Sanfuentes y Alessandri ejercieron dos tipos de censura, la judicial y la administrativa-policial, ambas realizadas con posterioridad a la publicación de los impresos, no existiendo censura previa hasta el golpe militar de 1924. Consideramos que la censura judicial no tuvo los efectos esperados debido a que la legislación era insuficiente para procesar y condenar penalmente a la prensa obrera por sus campañas de denuncia y de organización de la rebelión social. Por lo tanto, los gobiernos en cuestión utilizaron la censura administrativa-policial, consistente en allanamientos, asaltos y destrucción de las imprentas, la que, si bien bordeaba la ilegalidad, resultó más efectiva para silenciar de manera inmediata los medios de comunicación.

Sólo, tras la segunda intervención militar, se modificó el marco legal heredado del siglo XIX y se creó una nueva ley de publicidad que logró establecer un sistema de control estricto sobre las imprentas, la prensa y otros medios de comunicación, y se instauraron límites a los contenidos políticos que podían ser emitidos por esos medios. Asimismo, permitió recabar información de la prensa y generar un sistema de autorizaciones para los nuevos medios, el que sirvió de base para el tipo de censura que establecería durante la dictadura de Carlos Ibáñez del Campo.

Recibido: 12 diciembre 2015 Aceptado: 9 marzo 2016

\section{REFERENCIAS}

\section{Bibliografía impresa:}

Ricardo Anguita, Leyes publicadas en Chile desde 1810 hasta el 1 de junio de 1912. Santiago, Imprenta Barcelona, 1912.

Luis Aracena Aguayo, "Legislación y libertad de imprenta", Memoria para optar al grado de Lic. En Ciencias Jurídicas Universidad de Chile, 1953.

Osvaldo Arias, La prensa obrera en Chile. 1900-1930. Chillán, Convenio CUT-UTE, 1970.

Robert Darnton, Censores trabajando. De cómo los Estados dieron forma a la literatura. México, Fondo de Cultura Económica, 2014.

Raimundo De la Cruz, "La democracia y la libertad de prensa", Prensas de la Universidad de Chile, Santiago, 1940. 
Peter DeShazo, Trabajadores industriales y sindicatos en Chile. 1902-1927, Santiago, Centro de Investigaciones Barros Arana, Dibam, 2007.

Enrique Didier Silva, "De la libertad de imprenta", Memoria para optar al grado de Lic. En Facultad de Ciencias Jurídicas y Sociales, Universidad de Chile, 1933.

Ricardo Donoso, Las ideas políticas en Chile. México, Fondo de Cultura Económica, 1946.

Ricardo Donoso, La sátira política en Chile. Santiago, Imprenta Universitaria, 1950.

Ricardo Donoso, Alessandri, agitador y demoledor. Cincuenta años de historia política de Chile. Vol. I. México, Fondo de Cultura Económica: 1952.

Sergio Grez, Historia del comunismo en Chile. La era de Recabarren. 1912-1924. Santiago. Ed. Lom, 2014.

Román Gubern, La Censura. Función política y ordenamiento jurídico bajo el franquismo. 19361975. Barcelona, Ediciones Península, 1981.

Mónica Jaramillo [et. al.] "El Estado contra la prensa anarquista: el caso "Verba Roja" Tesis, Universidad de Santiago, 1997.

Julio César Jobet, Recabarren y los orígenes del movimiento obrero y el socialismo chileno. Santiago, Ed. Prensa Latinoamericana S. A., 1973.

Manuel Lagos, "Viva la anarquía: sociabilidad, vida y prácticas culturales anarquistas SantiagoValparaíso, 1890-1927”, Tesis Magíster en Historia, Usach, 2009.

Manuel Lagos, Los Subversivos. Las maquinaciones del poder. "República" de Chile, 1920. Santiago, Ed. Quimantú, 2012.

Hernán Millas, Los señores censores. Santiago, Editorial Antártica, 1985

Víctor Muñoz, Armando Triviño: wobblie. Hombres, ideas y problemas del anarquismo en los años 20. Santiago, Ed. Quimantú, 2009.

Víctor Muñoz, Cuando la patria mata. La historia del anarquista Julio Rebosio. Santiago, Ed. Usach, 2011.

Germán Orrego Vicuña, "Delitos de imprenta o de publicación", Memoria de prueba, Lic. En Ciencias Jurídicas Universidad de Chile, 1937.

Carlos Ossandón y Eduardo Santa Cruz, El estallido de las formas. Chile en los albores de la "cultura de masas". Santiago, Ed. Lom-ARCIS: 2005.

Julio Pinto, Verónica Valdivia, ¿Revolución proletaria o querida chusma? Socialismo y alessandrismo en la pugna por la politización pampina. 1911-1932. Santiago, Ed. Lom, 2001.

Camilo Plaza, "Organismos fundamentales del Estado: la función político-policial de la Dirección General de Investigaciones. 1933-1948", Tesis para optar al grado de Magíster en Historia, Universidad de Santiago de Chile, 2015.

Camilo Plaza y Víctor Muñoz, "La ley de Residencia de 1918 y la persecución a los extranjeros subversivos", Revista de Derechos Fundamentales, Universidad del Mar, No. 10, 2013, pp. 107136. 
Gonzalo Rojas y Jorge Rojas, "En búsqueda de una definición: notas para el estudio de la policía y los trabajadores durante el gobierno de Alessandri (1920-1924)", Boletín de Historia y Geografía. Instituto de Estudios Superiores Blas Cañas, No. 14, 1998.

Jorge Rojas, "La prensa obrera chilena: el caso de la Federación Obrera y Justicia. 1921-1927" en Olga Ulianova, Manuel Loyola y Rolando Alvarez, 1912-2012, El siglo de los comunistas chilenos. Santiago: Instituto de Estudios Avanzados, USACH, 2012.

Eduardo Santa Cruz, Análisis histórico del periodismo chileno. Santiago, Nuestra América Ediciones, 1988.

Raul Silva Castro, Prensa y periodismo en Chile. 1812-1956. Santiago, Edit. Del Pacífico, 1958.

Bernardo Subercaseaux, Historia del libro en Chile (alma y cuerpo), Santiago, Ed. Lom, 2000.

Waldo Urzúa, Del pesquisa al investigador. Santiago, Talleres Gráficos La Nación, 1947.

Olga Ulianova y Alfredo Riquelme, Chile en los archivos soviéticos: 1922-1991. Tomo II. Komintern y Chile. 1931-1935. Santiago, Centro de Investigaciones Diego Barros Arana, Lom Ediciones, 2009.

Verónica Valdivia, "Yo el León de Tarapacá. Arturo Alessandri Palma. 1915-1932” en Revista Historia, Vol. 32, 1999, pp. 485-551.

Verónica Valdivia "Los tengo plenamente identificados' Seguridad interna y control social en Chile. 1918-1925", (manuscrito inédito), 2015.

Augusto Varas, Felipe Agüero, Fernando Bustamante, Chile, democracia y Fuerzas Armadas. Santiago, Flacso, 1980.

Gonzalo Vial, Historia de Chile (1891-1973) Vol. II: Triunfo y decadencia de la oligarquía. 18911920. Ed. Santillana, Santiago, 1982.

Gonzalo Vial, Historia de Chile. 1891-1973. Vol. III: Arturo Alessandri y los golpes militares. 1920-1925. Santiago, Ed. Santillana, 1986.

Carlos Vicuña Fuentes, La Tiranía en Chile, Santiago, s.n., 1938

\section{Prensa:}

El Despertar de los Trabajadores, Iquique, 1922-1925

El Diario Ilustrado, 1919

El Surco, Iquique, 1919-1921

Justicia, Santiago, 1924

Juventud, Santiago, 1921

La Federación Obrera de Chile, 1921

La Gaceta de los Tribunales, Santiago, 1918-1920

La Nación, Santiago, 1924-1925

Tribuna Libertaria, Santiago, 1924-1925

Verba Roja, 1919

\section{Archivos:}

Archivo Regional de Tarapacá, Fondo Intendencia de Tarapacá. Vols. 1328, 1261

Archivo Nacional de la Administración, Fondo Ministerio del Interior, Vols. 5074, 5190, 6130, 6141; y Fondo Ministerio de Guerra, Vol. 4520. 
Código Penal de la República de Chile, Santiago, Imprenta de la República, 1874.

Boletín de Sesiones Ordinarias y Extraordinarias, Cámara de Senadores, 1872 y 1919

Boletín de Sesiones Ordinarias y Extraordinarias, Cámara de Diputados, 1918-1923

\section{Bibliografía electrónicas o digitalizadas:}

Rolando Alvarez, "La matanza de La Coruña. Chile, 1925", disponible en http://www.luisemiliorecabarren.cl/files/recursos/Matanza_en_La_Coruna.pdf (Consultada el 20 de marzo 2015)

Víctor Muñoz, "Cuando las bombas son de papel" Los trabajadores, el Estado y la propaganda anarquista impresa. Región chilena, 1915-1927" en Pacarina del Sur, Revista de Pensamiento Crítico Latinoamericano, Año 6, No. 22, enero-marzo 2015. Edición electrónica disponible en http://www.pacarinadelsur.com/home/huellas-y-voces/200-cuando-las-bombas-son-de-papel-lostrabajadores-el-estado-y-la-propaganda-anarquista-impresa-region-chilena-1915-1927

Víctor Muñoz, "Oro peruano y represión obrera: Los últimos días del anarquista Julio Rebosio Barrera" en http://www.anarkismo.net/article/11948 (consultado el 29 de mayo de 2015)

\section{Fuentes electrónicas y/o digitalizadas:}

Ministerio de Justicia, Decreto Ley 425, Sobre abusos de la publicidad, 26 de marzo 1925. Disponible en http://bcn.cl/1mtob , (consultada el 16 de junio 2014)

Ministerio del Interior, Ley No. 3494, que otorga al presidente de la República facultades para restringir ciertas libertades, 6 de febrero 1919. Disponible en http://bcn.cl/1ql17 (consultada el 12 de junio de 2014)

Ministerio del Interior, Ley núm. 3446 que impide la entrada al país o la residencia en él de elementos indeseables, 12 de diciembre 1918. Disponible en http://bcn.cl/1qke6 (consultada el 11 de junio de 2014)

José Victorino Lastarria, Proyecto de libertad de imprenta presentado al Congreso Nacional, Santiago, Imprenta del Progreso, 1849 Disponible en http://www.memoriachilena.cl/602/w3-article$\underline{86272 . h t m l}$ (consultado el 20 de marzo 2015)

Ley sobre Abusos de la Libertad de Imprenta, 17 de julio 1872, Disponible en http://bcn.cl/1tr0v (visitado el 20 de marzo 2015)

Constitución Política de la República de Chile, 25 de mayo de 1833. Disponible en http://bcn.cl/1m3sn (consultada el 15 marzo 2015) 